\title{
Application of Ionic Liquids for the Recycling and Recovery of Technologically Critical and Valuable Metals
}

\author{
Grace Inman (1), Ikenna C. Nlebedim (1) and Denis Prodius *(D) \\ Ames Laboratory, Department of Energy U.S., Critical Materials Institute, Ames, IA 50011-3020, USA; \\ inmang2000@gmail.com (G.I.); nlebedim@ameslab.gov (I.C.N.) \\ * Correspondence: prodiusd@ameslab.gov; Tel.: +1-515-294-7901
}

check for updates

Citation: Inman, G.; Nlebedim, I.C.; Prodius, D. Application of Ionic

Liquids for the Recycling and Recovery of Technologically Critical and Valuable Metals. Energies 2022, 15, 628. https://doi.org/10.3390/ en15020628

Academic Editor: Jeong-Hun Park

Received: 4 December 2021

Accepted: 9 January 2022

Published: 17 January 2022

Publisher's Note: MDPI stays neutral with regard to jurisdictional claims in published maps and institutional affiliations.

Copyright: (C) 2022 by the authors. Licensee MDPI, Basel, Switzerland. This article is an open access article distributed under the terms and conditions of the Creative Commons Attribution (CC BY) license (https:// creativecommons.org/licenses/by/ $4.0 /)$.

\begin{abstract}
Population growth has led to an increased demand for raw minerals and energy resources; however, their supply cannot easily be provided in the same proportions. Modern technologies contain materials that are becoming more finely intermixed because of the broadening palette of elements used, and this outcome creates certain limitations for recycling. The recovery and separation of individual elements, critical materials and valuable metals from complex systems requires complex energy-consuming solutions with many hazardous chemicals used. Significant pressure is brought to bear on the improvement of separation and recycling approaches by the need to balance sustainability, efficiency, and environmental impacts. Due to the increase in environmental consciousness in chemical research and industry, the challenge for a sustainable environment calls for clean procedures that avoid the use of harmful organic solvents. Ionic liquids, also known as molten salts and future solvents, are endowed with unique features that have already had a promising impact on cutting-edge science and technologies. This review aims to address the current challenges associated with the energy-efficient design, recovery, recycling, and separation of valuable metals employing ionic liquids.
\end{abstract}

Keywords: critical materials; ionic liquids; recycling; recovery from e-waste; extraction processes

\section{Introduction}

Increasing awareness of climate change and resource depletion has led to a global shift towards greener alternative technologies. Hence, there is higher demand for non-fossil fuel-based technologies, such as electric vehicles, wind turbines, fuels cells, and batteries. Advancements in these areas are limited by the resiliency in the supply of highly valued metals, such as the precious metals, the rare earth metals, and battery components, all of which play a crucial role in developing sustainable technological processes [1].

The assured supply and resilience of these critical materials are essential to the economic prosperity and national defense of many countries [2]. Currently, the United States and other developed nations are substantially dependent on foreign sources for many of their critical metals [3]. This dependence poses a problem as political tensions between some countries and the impact of the COVID-19 pandemic have led to decreased imports due to vulnerable supply chains [4].

To remedy this, the U.S. Department of Energy supports multiple initiatives to secure the supply of critical materials through diversifying supply, developing substitutes and recycling [2]. There are also efforts in other regions, especially in Europe, Japan, Australia, Canada, etc. [3,4]. These ecopolitical factors, along with the increasing acceptance of Green Chemistry principles for sustainable technologies, have led to a need for new processing techniques for technologically high valued metals.

One of the directions to address these technological concerns is the application of ionic liquids in the recovery and recycling of critical materials. Ionic Liquids (IL) are organic salts consisting of an organic cation and usually an inorganic anion [5]. Due to the 
poor ionic coordination and the delocalized charge of at least one ion, ionic liquids can be characterized by their low melting points, low vapor pressure, flammability, high stability, and recyclability.

ILs are also often referred to as designer solvents, as the substitution of one or more ions in the salt can greatly change the properties of the solvent, and the solvent can be fine-tuned for specific processes [6]. As opposed to traditional solvents, usually volatile organic compounds (VOC), ionic solvents do not emit environmental pollutants into the atmosphere [7]. Although ILs have been designated as 'green' solvents, the substances' solubility in water can potentially lead to aquatic contamination. Also, recent studies have revealed that the structure of the IL, mainly the cation component, strongly influences toxicity [8].

The ILs most investigated so far include various substitutions of imidazolium, pyridinium, ammonium, and phosphonium cations (Figure 1) associated with anions, such as halides, tetrafluoroborate $\left[\mathrm{BF}_{4}\right]^{-}$, hexafluorophosphate $\left[\mathrm{PF}_{6}\right]^{-}$, bis(trifluoromethylsulfonyl)imide $\left[\mathrm{Tf}_{2} \mathrm{~N}\right]^{-}$, carboxylates $\left[\mathrm{RCO}_{2}\right]^{-}$, alkyl sulfates $\left[\mathrm{C}_{\mathrm{n}} \mathrm{SO}_{4}\right]^{-}$, and alkyl sulfonates $\left[\mathrm{CnSO}_{3}\right]^{-}$. Due to their complexity compared to traditional solvents, the high cost of ILs is one of the hurdles preventing large-scale applications [6,9] (Table 1).<smiles></smiles><smiles>[R7][N+]1([R])CCCC1</smiles><smiles></smiles><smiles></smiles><smiles>[R][N+]([R9])([2H])[2H]</smiles>

Imidazolium Pyrrolidinium Morpholinium Pyridinium<smiles>[R]N1C=Cc2ccccc2C1</smiles><smiles>[R]N1CCCCC1</smiles><smiles>CCCN1CC=NCC1</smiles><smiles>[2H][Pb]([2H])([2H])[2H]</smiles>

Isoquinolinium

Piperidinium

Pyrazinium

\section{Phosphonium}<smiles>O=S(=O)([O-])NS(=O)(=O)C(F)(F)C(F)(F)F</smiles><smiles></smiles>

$$
\begin{array}{r}
\text { F-, }^{-} \mathrm{Cl}^{-}, \mathrm{Br}, \mathrm{I}^{-} \\
\mathrm{X}^{-} \text {(Halide-) }
\end{array}
$$$$
\mathrm{PF}_{6}{ }^{-}, \mathrm{SiF}_{6}{ }^{2-}, \mathrm{NO}_{3}
$$

$\mathrm{LnX}_{6}{ }^{3-}, \mathrm{FeCl}_{4}^{-}$, $\mathrm{CoCl}_{4}{ }^{2-}, \mathrm{CuCl}_{4}{ }^{2-}$, $\mathrm{AlCl}_{4}^{-},\left[\operatorname{Ln}\left(\mathrm{Tf}_{2} \mathrm{~N}\right)_{\mathrm{n}}\right]^{3-\mathrm{n}}$<smiles>[R]C(=O)O[14CH3]</smiles><smiles>O=[N+]([O-])c1ncoc1[N+](=O)[O-]</smiles><smiles>Nc1nnno1</smiles><smiles></smiles>

Figure 1. Common cations and anions of ionic liquids. Reprinted from Coordination Chemistry Reviews, 363, D. Prodius, A.-V. Mudring, Rare earth metal-containing ionic liquids, 1-16, Copyright (2018) [10], with permission from Elsevier. 
Table 1. A comparison of ionic liquids with organic solvents [9].

\begin{tabular}{lll}
\hline \multicolumn{1}{c}{ Property } & \multicolumn{1}{c}{ Organic Solvents } & \multicolumn{1}{c}{ Ionic Liquids } \\
\hline Number of solvents & $>1000$ & $>1,000,000$ \\
Applicability & Single function- & Multifunction \\
Catalytic ability & Rare & Common and tunable \\
Chirality & Rare & Common and tunable \\
Vapor pressure & Obeys the Clausius-Clapeyron Equation & Negligible under normal conditions \\
Flammability & Usually flammable & Usually nonflammable \\
Solvation & Weakly solvating & Strongly solvating \\
Tunability & Limited range of solvents available & Unlimited range means 'designer solvents' \\
Polarity & Conventional polarity concepts apply & Polarity concept questionable \\
Cost & Normally inexpensive & 2 to 100 times the cost of organic solvents \\
Recyclability & Green imperative & Economic imperative \\
Viscosity/cP & $0.2-100$ & $22-40,000$ \\
Density/g cm & $0.6-1.7$ & $0.8-3.3$ \\
Refractive index & $1.3-1.6$ & $1.5-2.2$ \\
\hline
\end{tabular}

The use of ILs as a replacement for traditional toxic volatile organic compounds (VOCs) aligns with the green chemistry principle of using benign solvents and auxiliaries. VOCs are a family of highly volatile and flammable chemicals that are regulated in sever-al countries. The use of ILs to substitute or reduce use of VOCs is a goal that could have significant positive environmental impact.

The wide-ranging combinations of IL cation and anion components provides a great variety of basic physical properties (Table 2) [11], which can be further applied for tunable interactions and a variety of applications. The immiscibility of ILs with both water and nonpolar organic solvents, along with the ability to solubilize a large array of diverse materials, brings exciting opportunities in separation and recovery of critical elements [12]. The development of ILs shows a lot of promise for the metal extraction industry. Most studies of ILs are focused on solvent extraction; however, ILs also have potential in metal leaching, cementation, and electrowinning [13]. The practice of using ILs in metallurgy, sometimes referred to as ionometallurgy, is still in its beginning stages [13].

Table 2. Comparison of some selected properties for ionic liquids with [Aliquat $]^{+}$and $\left[\mathrm{C}_{8} \mathrm{mim}\right]^{+}$ cations [11].

\begin{tabular}{|c|c|c|c|c|c|c|}
\hline Structure of Cation & $\begin{array}{l}\text { Ionic } \\
\text { Liquid }\end{array}$ & $\begin{array}{l}\text { Viscosity, } \\
\eta(P a \cdot s)\end{array}$ & $\begin{array}{c}\text { Glass Transition, } \\
\operatorname{Tg}\left({ }^{\circ} \mathrm{C}\right)\end{array}$ & $\begin{array}{c}\text { Melting Point, } \\
\operatorname{Tm}\left({ }^{\circ} \mathrm{C}\right)\end{array}$ & $\begin{array}{c}\text { Decomposition, } \\
\operatorname{Td}\left({ }^{\circ} \mathrm{C}\right)\end{array}$ & $\begin{array}{c}\text { Solubility: } \\
\text { Miscible/Immiscible }\end{array}$ \\
\hline \multirow{6}{*}{$n-\mathrm{C}_{8} \mathrm{H}_{17}-\mathrm{N}_{\mp} n-\mathrm{C}_{8} \mathrm{H}_{17}$} & [Aliquat][TSA] & - & - & 77.98 & 241 & $\mathrm{E}, \mathrm{EA} / \mathrm{W}, \mathrm{H}$ \\
\hline & [Aliquat][DCA] & 0.300 & -89.94 & - & $>300$ & $\mathrm{E} / \mathrm{W}, \mathrm{H}$ \\
\hline & [Aliquat][SAC] & 2.824 & -54.02 & - & 205 & $\mathrm{E}, \mathrm{EA} / \mathrm{W}$ \\
\hline & [Aliquat][TFA] & 0.740 & -70.95 & - & 183 & $\mathrm{E}, \mathrm{H}, \mathrm{EA} / \mathrm{W}$ \\
\hline & [Aliquat] $\left[\mathrm{Tf}_{2} \mathrm{~N}\right]$ & 0.354 & -81.42 & - & $>300$ & $\mathrm{E}, \mathrm{EA} / \mathrm{W}, \mathrm{H}$ \\
\hline & [Aliquat][TfO] & - & - & - & $>300$ & $\mathrm{E}, \mathrm{EA} / \mathrm{W}, \mathrm{H}$ \\
\hline 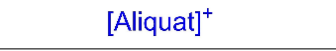 & [Aliquat][SCN] & 1.017 & - & - & - & $\mathrm{E}, \mathrm{EA} / \mathrm{W}, \mathrm{H}$ \\
\hline \multirow[b]{7}{*}[\mathrm{C}_{8}\mathrm{mim}]{$^{+}$} & {$\left[\mathrm{C}_{8} \mathrm{mim}\right][\mathrm{TSA}]$} & - & - & 89.48 & $>300$ & $\mathrm{~W}, \mathrm{EA} / \mathrm{H}, \mathrm{E}$ \\
\hline & {$\left[\mathrm{C}_{8} \mathrm{mim}\right][\mathrm{DCA}]$} & 0.034 & -92.93 & - & 250 & $\mathrm{~W}, \mathrm{EA} / \mathrm{H}, \mathrm{E}$ \\
\hline & {$\left[\mathrm{C}_{8} \mathrm{mim}\right][\mathrm{SAC}]$} & 0.389 & -63.68 & - & 245 & $\mathrm{EA} / \mathrm{H}, \mathrm{E}$ \\
\hline & {$\left[\mathrm{C}_{8} \mathrm{mim}\right][\mathrm{TFA}]$} & 0.054 & -88.90 & - & 190 & $\mathrm{EA} / \mathrm{H}, \mathrm{E}$ \\
\hline & {$\left[\mathrm{C}_{8} \mathrm{mim}\right]\left[\mathrm{Tf}_{2} \mathrm{~N}\right]$} & 0.087 & -86.45 & - & $>300$ & $\mathrm{EA} / \mathrm{W}, \mathrm{H}, \mathrm{E}$ \\
\hline & {$\left[\mathrm{C}_{8} \mathrm{mim}\right][\mathrm{TfO}]$} & 0.100 & -92.30 & - & $>300$ & $\mathrm{EA} / \mathrm{W}, \mathrm{H}, \mathrm{E}$ \\
\hline & {$\left[\mathrm{C}_{8} \mathrm{mim}\right][\mathrm{SCN}]$} & 0.070 & - & - & 226 & $\mathrm{~W}, \mathrm{EA} / \mathrm{H}, \mathrm{E}$ \\
\hline
\end{tabular}

[Anions]: $[$ TSA] $=4$-toluenesulphonate, $[\mathrm{DCA}]=$ dicyanamide, $[\mathrm{SAC}]=$ saccharinate, $[\mathrm{TFA}]=$ trifluoroacetate $\mathrm{W}=$ water $\mathrm{H}=$ hexane, $\mathrm{EA}=$ ethyl acetate, $\mathrm{E}=$ ether. Water content of each ionic liquid: $<20$ ppm.

The recovery and reuse of ILs also play an important role in the commercialization of applicable technologies, and it is essential for the effective consumption of resources and environmental conservation. The recycling processes can be different and are typically based on the hydrophobicity/hydrophilicity of an IL. However, a key goal of the recycling processes is to reuse the ILs in subsequent cycles of a technology. One of the options 
for reuse of ILs, which is widely applied in hydrophilic thermally stable ILs, is thermal treatment [14]. Other techniques are centrifugation, adsorption, reverse osmosis, and electrodialysis, etc. [15].

This paper will cover the most recent findings of ILs used in high valued metals, such as $\mathrm{Ag}, \mathrm{Cu}, \mathrm{Pd}, \mathrm{Li}, \mathrm{Co}, \mathrm{Mn}$, In, Ga, and the rare earths (RE), with an emphasis on the recycling from electronic waste products.

\subsection{Metal Recovery by Ionic Liquid}

Metal recovery usually consists of three steps: leaching, extraction, and stripping. ILs are most often utilized in the leaching or extraction phases. For typical solvent extraction, an aqueous feed is contacted with an immiscible organic solvent carrier containing the extractant (the active species that extracts the desired solute). Some ILs, usually functionalized ILs, can function both as an extractant and diluent; however, most pure ILs are used purely as diluents or solvents for common industrial extractants.

In both cases, it is important to consider several aspects when designing an experiment with ILs. The hydrophobicity, for example, is important for maintaining an immiscible solvent extraction system. For this reason, anions, such as $\left[\mathrm{BF}_{4}\right]^{-},\left[\mathrm{PF}_{6}\right]^{-}$and $\left[\mathrm{NTf}_{2}\right]^{-}$, are commonly used for their high hydrophobicity and good thermal and electrochemical stability [13,16]. For non-fluorinated anions, quaternary ammonium or phosphonium cations with long alkyl chains can make hydrophobic ILs. This comes in handy when designing bi-functional ILs, which can have metal coordinating groups attached to the anion and cation.

\subsection{Functionalized Ionic Liquids}

Functionalized ILs, also known as task-specific ionic liquids (TSIL), are created when moieties of common extractants or complexing agents are added to the anion and/or cation of the IL. Mono-functional ILs usually consists of a functionalized cation and hydrophobic fluorinated salt, such as $\left[\mathrm{Tf}_{2} \mathrm{~N}\right]^{-}$. For example, the carboxylic acid-based cation, betainium, $[\mathrm{Hbet}]^{+}$, is often used in metal oxide dissolution and results in high efficiency even as a pure IL $[17,18]$.

Furthermore, a DEHP- based IL, [C 6 mim][DEHP], has also been reported, although this IL is too hydrophilic to function alone, therefore $\left[\mathrm{N}_{1444}\right]\left[\mathrm{Tf}_{2} \mathrm{~N}\right]$ was used as a diluent [19]. One of the main drawbacks of functionalized ILs is high viscosities at room temperature, resulting in impracticably slow reaction rates. To overcome this, another IL or solvent can dilute TSILs; however, this appears to defeat the point of functionalizing to remove extractant-solvent partitioning in the first place.

One drawback of fluorinated anions is they can decompose when heated in the presence of water, giving off hydrofluoric acid (HF). Rather than relying on the anion for the hydrophobicity of the IL, hydrophobic cations can be used instead. Quaternary ammonium or phosphonium cations with long alkyl chains are typically used for this purpose. However, in some cases, very long alkyl chains increase steric hindrance and decrease distribution ratios.

One of the most popular quaternary ammonium cations is made from commercial ion exchanger Aliquat 336. With the hydrophobicity taken care of by the cation, there are more options for functionalized anions. As such, acid-base neutralization has been used to combine $[\mathrm{A} 336]^{+}$with phosphonic acid-based anions, such as [P204] ${ }^{-}$, phosphinic acid-based [Cynanex 272] $]^{-}$, and carboxylic acid-functionalized anions as well as extractant-

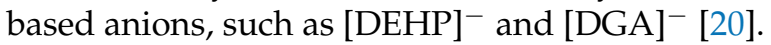

\subsection{Reaction Mechanism}

Liquid-liquid extraction is mainly driven by extracting the least hydrated complex in the aqueous phase to the organic phase. Extractants are used to dehydrate metal ions, increasing their hydrophobicity, and facilitating transport to the extracting phase. Most 
often, extractants form cationic complexes with metal ions, which are then swapped with the cation of the IL; this is called cation exchange.

Neutral extractants, such as carbamoylmethylphosphine oxide (CMPO), tributyl phosphate (TBP), maloamides (MA), and diglycolamine (DGA) typically participate in cation exchange, especially when encouraged by less hydrophobic cationic components. Anion exchange and ion-pair exchange are also potential mechanisms for IL solvent extraction systems. Basic extractants, like trialkyl amines and pure ILs, have been reported to follow the anion exchange mechanism.

Acidic extractants have been reported for all kinds of reaction mechanisms; Mono2-ethylhexyl (2-ethylhexyl)phosphonate (PC-88A) and Di-(2-ethylhexyl)phosphoric acid (DEHPA) are said to follow a solvation mechanism. Unfortunately, both anion and cation exchange can result in loss of ionic components to the aqueous phase and thus contamination and/or destabilization of the liquid-liquid system. This is a hurdle that needs to be overcome when designing sustainable and regenerable IL extraction methods $[20,21]$.

\subsection{Salting Effect}

Another aspect to consider when designing a liquid-liquid extraction system is the addition of inorganic salts to the aqueous phase- also known as salting out agents, which can increase the extraction efficiency. Both the cation and anion components of the salt can influence extraction. Sun et al. studied the effect of various sodium salts on the extraction of $\mathrm{Pr}^{3+}$ ions with [A336] $\left[\mathrm{NO}_{3}\right]$. They found that the extraction percentage of $\mathrm{Pr}^{3+}$ was dependent on synergistic relationship of the salt effect and Hofmeister bias.

The salting out effect was demonstrated by varying the concentration of inorganic salt or volume of the organic phase and observing that the salt concentration was the only variable that influenced extraction ability. The Hofmeister bias asserts that salts with a greater hydration ability prefer to remain in the aqueous phase, while poorly hydrated ions prefer to transfer to the organic phase. Due to these phenomena, it was concluded that anions with poor hydration and strong complexing ability could enhance the extraction of $\mathrm{Pr}^{3+}$ in [A336] $\left[\mathrm{NO}_{3}\right]$. The observed trend in anions from greatest to least extraction percentage was $\mathrm{Cl}^{-}>\mathrm{Br}^{-}>\mathrm{NO}_{3}{ }^{-}>\mathrm{PF}_{6}{ }^{-}$[22].

The influence of inorganic cations was also studied in a 2020 report by Lommelen et al. [23]. They used different chloride salts to aid the extraction of $\mathrm{Co}(\mathrm{II}), \mathrm{Zn}(\mathrm{II})$, and $\mathrm{Cu}$ (II) with basic extractant methyltriocyalammonium chloride (TOMAC). Compounds with higher charge densities are more likely to be hydrated and stable in the aqueous media. At high chloride salt concentrations, $\mathrm{Zn}$ (II) coordinated with more anions than its oxidation state allows creating a negatively charged chloro complex, which should have been very stable in water.

However, if the cation of the inorganic salt also had a high charge density, then it could effectively take free water molecules that would otherwise be available for the hydration of the $\mathrm{Zn}$ complex and the less hydrated $\mathrm{Zn}$ complex could then be extracted rather efficiently to the organic phase. Therefore, cations with greater hydration ability improved metal extraction the most: $\mathrm{Li}^{+}>\mathrm{Na}^{+}>\mathrm{K}^{+}>\mathrm{Rb}^{+}>\mathrm{Cs}^{+}$. Additionally, the effect of di- or trivalent salts were also studied.

Although it was predicted that highly hydratable polyvalent salts would increase extraction, they showed only a third of the efficiency of the monovalent salts. The scientists speculate these results stem from polyvalent salts tendency to form ion-pairs with low charge density [23]. In general, changing the cation, anion, concentration of an added inorganic salt are ways to tailor a SX system for specific purposes.

\subsection{Stripping Agents}

After the IL is loaded with the desired metal ions, the metal ion needs to be removed. This can be done in different ways depending on the final product requirements. Stripping, precipitation, or electrowinning are a few options. Organic solvents can be used to strip IL, although with the consequence of contaminating the product streams and compromising 
the "greenness" of the process. Alternatively, supercritical $\mathrm{CO}_{2}\left(\mathrm{Sc}-\mathrm{CO}_{2}\right)$ can be used as a stripping agent.

Sc- $-\mathrm{CO}_{2}$ is a great choice due to its high solubility, low reactivity, and low toxicity. Furthermore, $\mathrm{Sc}-\mathrm{CO}_{2}$ is highly soluble in ILs, while most ILs are rarely soluble in $\mathrm{Sc}-\mathrm{CO}_{2}$. $\mathrm{Sc}-\mathrm{CO}_{2}$ combined IL systems have been reported for the recovery of various lanthanides, actinides, and transition metals $[20,24,25]$. When picking a stripping agent, it is important to consider if the agent can be effectively regenerated or allow for future reuse of the stripped IL. Reduction of waste products should be a major consideration when designing any chemical process.

In metal extraction processes employing hydrophobic ILs, the acidic $\left(\mathrm{HCl}, \mathrm{H}_{2} \mathrm{SO}_{4}\right.$, EDTA) or basic $(\mathrm{NaOH}$, ammonia) stripping agents are favorable [26,27]. Apart from the efficient and reversible extraction suitability for the high-value metals, these approaches can also be used in solving environmental problems associated with, for example, removal of low-concentration toxic metals, such as $\mathrm{Pb}$ (II) and $\mathrm{Cd}$ (II) (Figure 2).

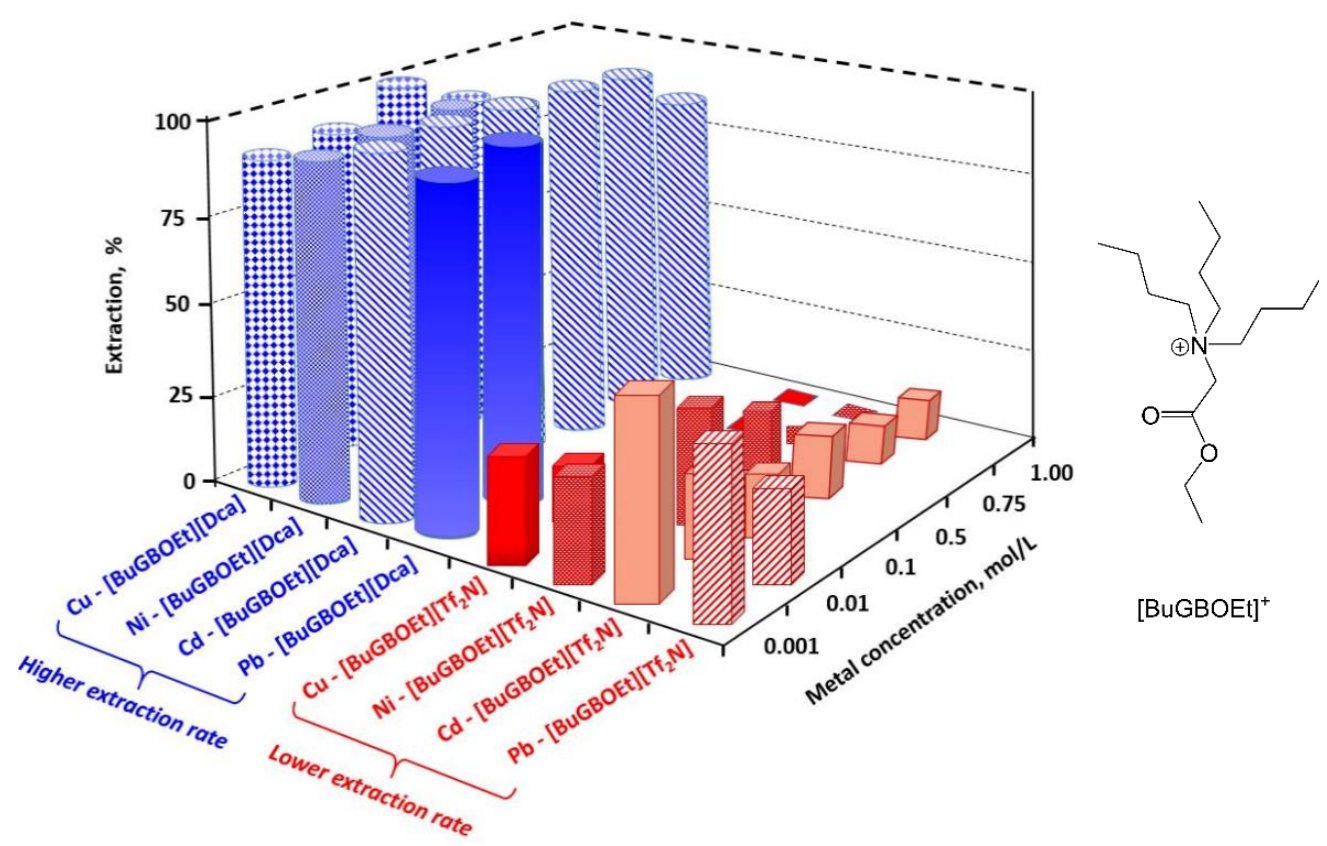

Figure 2. Extraction yields $(\% \mathrm{E})$ for $\mathrm{Cu}^{2+}, \mathrm{Ni}^{2+}, \mathrm{Pb}^{2+}$, and $\mathrm{Cd}^{2+}$ extracted with cationic ester derivative of betaine tri( $n$-butyl)[(2-ethoxy-2-oxoethyl]ammonium salts: $[\mathrm{DCA}]^{-}$(blue) and $\left[\mathrm{Tf}_{2} \mathrm{~N}\right]^{-}$(red). Data from [26].

As one of the recent successful examples of ILs recyclability, Dhiman and Gupta revealed no noticeable change in extraction of germanium oxide from Zener diodes even after twelve successful extraction-stripping recycling cycles (with $\mathrm{HCl}$ solution) with the CyphosIL 104 (trihexyltetradecylphosphonium bis(2,4,4-trimethylpentyl)phosphinate) [28].

\section{Precious Metals and Copper}

Precious metals, such as $\mathrm{Au}, \mathrm{Ag}$, $\mathrm{Pd}$, and $\mathrm{Cu}$, are high-value metals often associated with coinage and electronic components. Electronic waste is a valuable source of critical metal; just one printed circuit board (PCB) can have a metal content up to 10-100-times higher than that of conventionally mined ore [29]. Therefore, there is a need for new techniques for recovering and separating these materials from urban mined mixed wastes. The first step in metal recovery and extraction is usually dissolution or leaching to create an aqueous metal ion solution.

Aqueous metal ions are much easier to deal with because they are more likely to form complexes with extractants and can be removed via liquid-liquid extraction. The most common method for electronic waste leaching, the hydrometallurgical method, involves 
the oxidative dissolution of metal compounds using acid. Since acid dissolves metals easily, many studies focus on recovering metals from acidic mediums. However, using copious amounts of acid is not the most environmentally benign route.

It is exciting to note that there have been promising studies recently published exploring acid-free leaching. Oxidative leaching can even be achieved using ILs as Binnemans group discovered [30]. This team found that phosphonium based trihalide ILs dissolved a broad range of metals, except for Pt and $\mathrm{Rh}$. The benefits of leaching with such ILs include reducing wastewater production, avoiding gaseous byproduct, and development of safe solvometallurgical approaches [30].

\subsection{Gold}

Gold can be recovered by ILs from several sources. The most current literature focuses mainly on the separation of gold from mined ore, natural water, and electronics. Gold is considered the most valuable substance in electronics and in 2010, around 300 tons of gold were used in electronic manufacturing per year. It is estimated that the concentration of gold in mobile phones is around 70 times higher than that of primary ore. Therefore, it is often more lucrative to mine gold from urban waste than from ore [29]. Certain authors recorded using the phosphonium-based IL, Cyphos-101 or Cyphos-109, a commercially available IL, as a successful extractant for $\mathrm{Ag}$, as well as $\mathrm{Au}$, from acidic solutions [31,32].

In 2019, Wang et al. published a paper [33] on Au extraction with upper critical solution temperature (UCST)-type ILs. A UCST IL is a type of thermoregulated ILs with increased solubility at higher temperature. Above a critical temperature, the components of the system are completely miscible, and a homogeneous system is formed. In the homogeneous phase, fast reaction between the metal ion and extractant can take place. Recreating a two-phase equilibrium is simply achieved by lowering the temperature again.

The entire process is referred to as Homogeneous Liquid-liquid Extraction (HLLE). UCST ILs have high potential for metal extraction as they can be used without toxic organic solvents and provide a solution to the problematic high viscosities of room temperature ILs. Among the most widely studied UCST ILs are [Hbet][Tf $\left.{ }_{2} \mathrm{~N}\right]$ and $[\mathrm{Chol}]\left[\mathrm{Tf}_{2} \mathrm{~N}\right]$, which has a critical point with water at $55^{\circ} \mathrm{C}$ and $72{ }^{\circ} \mathrm{C}$, respectively. Both ILs will be discussed later in this paper.

Wang et al. [33] tested three novel ILs and determined that [EtbetmMor][Tf $2 \mathrm{~N}]$ was the most efficient, with extraction efficiency of gold up to $97.8 \%$ from acidic chloride medium via an anion exchange mechanism. Gold could even be extracted selectively from a mixed-metal solution; no other metals had extraction efficiencies above $5 \%$. After extraction, gold could be recovered from the IL phase by precipitation stripping with oxalic acid. Furthermore, the [EtbetmMor][ $\left.\mathrm{Tf}_{2} \mathrm{~N}\right]$ could be easily recycled, enhancing the environmentally friendliness of this method [33].

The following year, the same group synthesized acetylcholine $\left([\mathrm{ACh}]\left[\mathrm{Tf}_{2} \mathrm{~N}\right]\right)$ for the recovery of Au. Acetylcholine IL ([ACh][Tf $\left.f_{2} \mathrm{~N}\right]$ was chosen for its good biocompatibility and suitability as both an extractant and solvent for gold recovery. The IL could reach an extraction efficiency of $98 \%$ and demonstrated extraction selectivity for Au over other precious metals. The authors mention that $[\mathrm{ACh}]\left[\mathrm{Tf}_{2} \mathrm{~N}\right]$ performance was optimized in conditions of high salinity and lower acidity, which could show potential for Au recovery from special mediums [34].

Boudesocque et al. studied the effect of the anions on $\mathrm{Au}$ and Pt halogeno complex extraction [35]. They synthesized ILs with tetra alkyl ammonium cations and various anions. All systems, devoid of diluents, demonstrated excellent extractability of Au with the more hydrophobic ions extracting the highest yield. They reported that extraction yield increases in the following order: $\mathrm{Tf}_{2} \mathrm{~N}^{-}<\mathrm{DCA}^{-}<\mathrm{SCN}^{-}$with all systems progressing via an anion-exchange mechanism. They found that $\mathrm{Tf}_{2} \mathrm{~N}$-ILs were suitable for efficient separation of $\mathrm{Au}$ and $\mathrm{Pt}$ from mixed $\mathrm{Au} / \mathrm{Pt}$ solutions.

In an interesting new approach, Guo et al. attempted to create a solid-phase extraction technique using carboxymethyl-diethyl ammonium ethyl cellulose (CMDEAEC), an IL 
with high swellability (Figure 3) [36]. A prepared metal solution was added to the adsorbent at room temperature. After reaching equilibrium, the solution was filtered through a membrane filter. CMDEAEC exhibited a maximum Au adsorption of $15 \mathrm{mg} / \mathrm{g}$ and extremely high adsorption selectivity for Au over other metals. Desorption was possible with a thiourea- $\mathrm{HCl}$ solution and the adsorbent was reused, however, with decreased efficiency after a couple cycles. CMDEAEC, being a relatively inexpensive and easily producible compound, has great potential for the environmentally friendly selective recovery of gold [36].
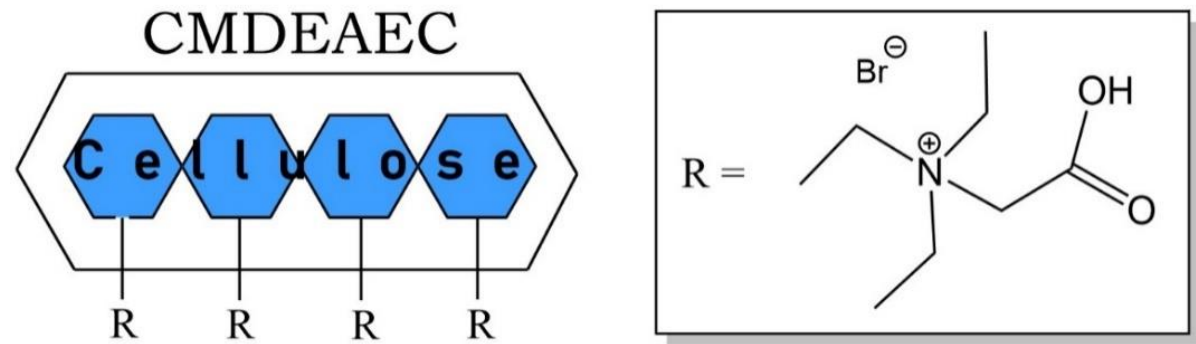

Figure 3. A general structural representation of carboxymethyl-diethyl ammonium ethyl cellulose (CMDEAEC) [36].

\subsection{Copper}

Copper is a very recyclable metal. The value of recycled copper scrap is very close to that of newly mined copper. According to the Copper Development Association Inc. the amount of copper recovered from recycled material in the U.S. is close to the amount mined from ore [37]. Due to the already high recyclability and abundance of copper, there is less incentive for novel extraction methods, and there are only a few recent studies on use of ILs for $\mathrm{Cu}$ recycling.

In 2015, Chen et al. published a comprehensive study on copper leaching from waste PCB with a variety of IL acids, $\left[\mathrm{BSO}_{3} \mathrm{HPy}\right] \mathrm{OTf},\left[\mathrm{BSO}_{3} \mathrm{HMIm} \mathrm{OTf},\left[\mathrm{BSO}_{4} \mathrm{HPy} \mathrm{HSO}_{4}\right.\right.$, $\left[\mathrm{BSO}_{4} \mathrm{Hmim}\right] \mathrm{HSO}_{4}$, and [Mim] $\mathrm{HSO}_{4}$. The authors reported that all IL tested could leach nearly $100 \%$ of $\mathrm{Cu}$ out of the circuit boards and concluded that $\mathrm{IL}$ acids with $\mathrm{HSO}_{4}{ }^{-}$were more efficient than IL acids with $\mathrm{CF}_{3} \mathrm{SO}_{3}{ }^{-}$[38].

Other ILs used to leach copper from an acidic medium include [Bmim]Cl, [Emim] $\mathrm{Cl}$, $[\mathrm{Bmim}]\left[\mathrm{BF}_{4}\right]$, and $[\mathrm{Bmim}]\left[\mathrm{PF}_{6}\right]$, out of which $[\mathrm{Emim}] \mathrm{Cl}$ and $[\mathrm{Bmim}]\left[\mathrm{PF}_{6}\right]$ were proven to be more effective [39]; and protic ionic liquids (PILs) consisting of a mix of trialkylamines with linear alkanoic acids [40]. PILs are produced through a mixture of a Brønsted acid and Brønsted base, such that molecular and ionic forms exist in equilibrium. Most notably, PILs have an acid proton on the cation. The benefit of this class of IL is that direct complexation of the PIL with the metal ion eliminates the need for a chelating agent, which offers lower potential costs and environment impacts.

As opposed to leaching, ILs can be used in $\mathrm{Cu}$ separation from other metals. One research group used amido-functionalized glycine-betaine-based ILs to separate cobalt, nickel, and copper. Their aim was to remove the need for a chelating agent by functionalizing ILs with chelating anions. To prevent the loss of the organic cation into the aqueous phase, they chose a betaine derivative based on its hydrophobicity and structural modularity. All synthesis products were rather inexpensive. Their data showed that $\left[\mathrm{Bu}_{3} \mathrm{NC}_{2} \mathrm{NHC}_{8}\right][\mathrm{Dca}]$ was the most effective IL for the separation of $\mathrm{Cu}$ (II) from the other two metals [41].

Another study [42] found that substituting the alcohol group of choline chloride, a special type of IL, with a thiol group can increase the solubility of the late transition metals, like copper. Choline chloride is an example of a deep-eutectic solvent (DES) that is created by the combination of an acid and a base and exhibits a lower melting point than its parent components. Binnemans et al. added the thiol group because complexing sulfur compounds tends to have a high selectivity and affinity for precious and late transition metals. The thiol-containing DES studies demonstrated lower viscosities, improved copper 
solubility, and consequently improved selective dissolution of $\mathrm{Cu}$ from $\mathrm{Fe}$, making it an excellent choice for end-of-life electronic waste [42].

\subsection{Palladium}

Palladium is largely used in catalytic converters, such as those in car exhaust systems, mainly non-diesel vehicles. As countries around the world increase regulations on emission to deal with air pollution problems and consumers shift away from diesel cars, the demand for palladium has skyrocketed, making it the most valuable of the four precious metals. For the last couple of years, the demand for palladium exceeded the supply, hence, the need for recycling [43].

Like most metals, Pd can be recovered from an acidic medium with phosphoniumbased Cyphos-101 IL, or alternatively with Cyphos-102 IL, or Cyphos-104 [44]. Experiments done by Katsuta and Tamura show that trioctylammonium nitrate ([HTOA][ $\left.\mathrm{NO}_{3}\right]$ ) saturated with water can be used to selectively extract $\mathrm{Pd}(\mathrm{II})$ and $\mathrm{Pt}(\mathrm{IV})$ from a mixture of transition metals. Although other studies have used $\left([\mathrm{HTOA}]\left[\mathrm{NO}_{3}\right]\right)$ as an $\mathrm{IL}$, this study is the first to use the IL without a diluent. This is because water-saturated ([HTOA][ $\left.\mathrm{NO}_{3}\right]$ ), which is a liquid at room temperature, has a relatively low viscosity and low aqueous solubility. Nearly $100 \%$ extraction was recorded for $\mathrm{Pd}$ and $\mathrm{Pt}$ from $1 \mathrm{M} \mathrm{HCl}$ solution [45].

Another method for the selective extraction of $\mathrm{Pt}$ and $\mathrm{Pd}$ is the used of magnetic nanomaterial modified with ILs. Magnetic Nanoparticles (MNPs) act as a good sorbent material due to their high surface area, fast kinetic properties, and easy manipulation under a magnetic field. In one experiment [46], MNPs based on magnetite nanoparticles $\left(\mathrm{Fe}_{3} \mathrm{O}_{4}\right)$ were coated in a silica or PEG shell and functionalized by IL grafting or synthesis of the IL directly on the surface of the shell.

The functionalized MNPs were combined with metal ion solutions of varying acidity, and, after equilibrium was reached, MNPs were separated from the solution by a NdFe-B magnet. The MNP functionalized with Cyphos-101, $\mathrm{Fe}_{3} \mathrm{O}_{4} \mathrm{PEG} @ \mathrm{Cyphos}{ }^{\circledR} \mathrm{IL}-101$ demonstrated the highest sorption ability towards $\mathrm{Pt}$ and $\mathrm{Pd}$ ions, as well as selective recovery from a mixed-metal solution. The research effectively used $\mathrm{HNO}_{3}$ as an eluent; however, they did not discuss the reusability of the MNPs. An externally controllable and regenerable sorbant like this could make a significant impact on extraction technologies, especially the amount of liquid waste produced if fully realized.

In a different approach for selective palladium extraction, Funaki et al. developed a biphasic extraction system with one IL acting as the extractant of solute into another IL medium [47]. Inspired by the use of THP-protected thiols as capping agents in the extraction of gold nanoparticles, the authors synthesized the TSILs, ILn ( $n=1$ and 2) bearing one or two tetrahydropyran-2H-yl (THP)-protected thiols with $\left[\mathrm{NTf}_{2}\right]^{-}$as the hydrophobic counter anion.

The extraction abilities of ILn and typical solvent di-n-hexylsulfide (DHS) in [Bmim][NTf ${ }_{2}$ ] were compared. Palladium chloride participated in a ligand-exchange reaction to form IL-soluble [Bmim] $\left[\mathrm{PdCl}_{3}\right.$ (ligand)] complexes. The key step here was that $\mathrm{Pd}(\mathrm{II})$ mediates THP deprotection of ILn. The selectivity ratio of Pd-Pt reached 72, with Pd extraction up $100 \%$. This report presented one of the highest specific Platinum Group Metal (PGM) separation and purification systems with IL solvent extraction. These results suggest that deprotection chemistry has great potential in future selective metal IL extraction processes.

\section{Battery Metals}

The following metals to be discussed play a vital role in rechargeable battery technologies, of which the market is rapidly expanding in conjunction with the popularity of Electric Vehicles (EVs). Most EVs are powered by Li-ion batteries. The lithium-ion cell consists of an anode, cathode, current collectors, separator, and nonaqueous electrolyte. The anode is usually granite and the cathode a lithium-based oxide, such as $\mathrm{LiCoO}_{2}, \mathrm{LiMn}_{2} \mathrm{O}_{4}, \mathrm{Li}_{2} \mathrm{MnO}_{3}$, and $\mathrm{LiNiMnCo}_{2}$. Therefore $\mathrm{Li}, \mathrm{Mn}, \mathrm{Co}$, and $\mathrm{Ni}$ markets have been evaluated to account for battery material consumption. 
According to Olivetti et al. [48], most lithium-ion materials are expected to meet near future demands. However, concern over rapid adoption of electric vehicles may strain the supply of some battery-grade materials. In 2019, 100\% of the U.S. manganese and 78\% of cobalt supplies were imported, leaving the metal supply vulnerable to geopolitical factors, especially with the Democratic Republic of Congo producing 60\% of the global supply of cobalt [49].

Lithium-ion batteries are popular due to their lightweight, high-energy density, and long-life cycles $[49,50]$. However, the technology is still improving, and the future of Li-ion batteries may require lower $\mathrm{Ni}$ content to optimize energy density. Consequently, the Global EV Outlook 2020 estimates that the amount of electric vehicle batteries retired by 2030 will be roughly equivalent to the current annual production of 100-120 GWh. They emphasize the need for battery reuse and recycling to decrease environmental liability and promote sustainable end-of-life practices [49].

\subsection{Lithium}

Primary sources of lithium include pegmatites and brines with salt lakes being the top exploitable resource. However, lithium in salt lake brines is always accompanied by magnesium and separating the two elements poses quite a challenge due to the elements' similar chemical properties. Current methods for $\mathrm{Li} / \mathrm{Mg}$ separation are time and reagent intensive, generate large amounts of waste, and have low Li recovery efficiency. IL systems are being developed to improve lithium recovery process.

Li et al. showcased the use of binary IL extractants for $\mathrm{Mg}$ removal to cut down on acid and base consumption [50]. [A336][V10] was synthesized from Aliquat 336 and Versatic Acid (a mixture of carboxylic acids) to be used in a three-stage counter-current extraction that boasted almost complete removal of magnesium and only $10 \%$ co-extraction of Li. Versatic acid was used because of its ability to extract magnesium impurities from concentrated lithium solution in a previous study [50]. Accordingly, [V10] ${ }^{-}$acted as the de-protonated acidic extractant molecule.

The binary IL was diluted with p-cymene, a bioderived solvent and proved to be more efficient on original brine rather than concentrated brine in an acid-based extraction where the reactions are driven by $\mathrm{pH}$. Whereas with binary extractants, the reactions are driven by the common ion effect and the ion in this case being chloride. The binary extractants dependency on the common ion effect has been the major obstacle for implementing binary extractants because the salt concentration of most feeds, including seawater is not sufficient to drive extraction. Salt lake brines, however, have high salt concentrations; hence, they present a desirable scenario for binary extractants.

Recent findings published in Angewandte Chemie (Applied Chemistry) [51] led to the development of novel macromolecules for targeted complex coordination and selective extraction. The Sessler group reported a hemispherand-strapped calix[4]pyrrole ligand for selective binding to $\mathrm{Li}^{+}$salts. Further research demonstrated that the molecule could operate successfully in solid-liquid or liquid-liquid phase extraction.

The Sessler process was mentioned in a review on metal separation for recycling and the authors only critique was the use of toxic solvents, such as chloroform [52]. The main accomplishment of ILs is as a greener substitute for traditional organic solvents. Combining ILs with this novel extractant would make the perfect combination. Sadly, there are likely many scenarios where ILs could be applied for exceptional process optimization, but the relative novelty of the field has prevented it thus far.

The study of ILs is often paired with supported liquid membrane (SLM) systems to improve efficiency as seen by Zante al in their efforts to selectively recover Li from brine. SILs feature an organic phase immobilized into the pores of a polymeric support placed between the feed and stripping aqueous solutions. In this work, a hydrophobic porous polyvinylidene fluoride (PVDF) membrane was impregnated with a mixture of $\left[\mathrm{C}_{4} \min \right]\left[\mathrm{Tf}_{2} \mathrm{~N}\right]$ and TBP. The benefits of an SLM include a continuous permeation situation 
where extraction and stripping occur simultaneously. However, the lack of stability of SML currently limits their scale-up potential [53].

As exhibited by the example of SMLs and the earlier magnetic nanoparticles, ILs can be placed in or on many different structures. Liu et al. attempted a similar approach with TBP $\left[\mathrm{C}_{4} \min \right]\left[\mathrm{Tf}_{2} \mathrm{~N}\right]$ [54]. Rather than impregnating a SLM, they used an electrodialysis system with a sandwiched liquid membrane consisting of the organic lithium-ion carrier and introduced two cation exchange membranes. The inner membranes acted as physical barriers between the feeding brine and receiving solution (Figure 4) [54].
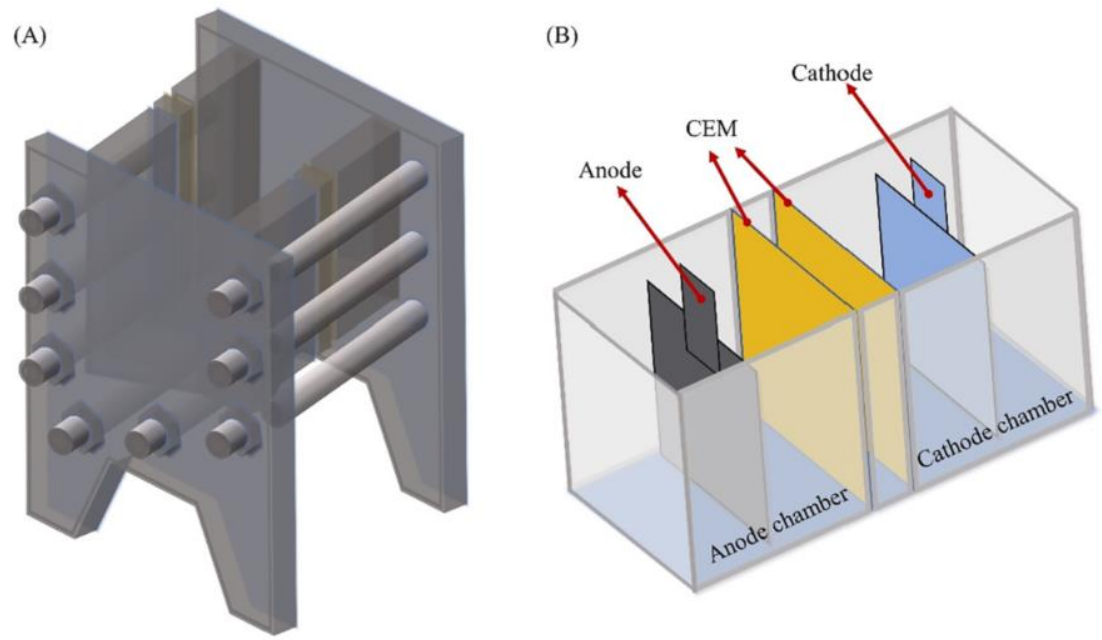

Figure 4. Schematic diagram of the electrodialysis device. (A) An assembled cell and (B) the placement of electrodes and CEMs in the cell. Reprinted from Desalination, 474, G. Liu, Z. Zhao, L. He, Highly selective lithium recovery from high Mg/Li ratio brines, 114185, Copyright (2020), with permission from Elsevier.

This system displays a great perspective on the application for Li recovery from $\mathrm{Mg} / \mathrm{Li}$ brines and offered potential minimal impact on the environment with excellent $\mathrm{Li}$ ion selectivity. Although, in both cases, a non-fluorinated, cheaper IL with similar efficiencies could have been used. The electrodialysis can also be applied towards lithium extraction from seawater, which, in the past, has not been considered feasible due to the low salt concertation [54].

\subsection{Cobalt}

Cobalt (Co) is the most critical element in lithium-ion batteries due to its vulnerable supply chain. Due to this, there have been many papers published focusing on cobalt recovery from battery cathodes and mixed cobalt and nickel waste. For convenience, some of these studies have been summarized in Table 3 below.

Table 3. Examples of Deep Eutectic Solvents (DES) used to leach cobalt from Li Battery cathodes.

\begin{tabular}{lccccccc}
\hline \multicolumn{1}{c}{ DES Used } & $\begin{array}{c}\text { Other } \\
\text { Reagents }\end{array}$ & $\begin{array}{c}\text { Temp } \\
\left({ }^{\circ} \mathbf{C}\right)\end{array}$ & $\begin{array}{c}\text { Time } \\
(\mathbf{h})\end{array}$ & $\begin{array}{c}\text { Leaching } \\
\text { Efficiency Co, \% }\end{array}$ & $\begin{array}{c}\text { Recovery of } \\
\text { Cobalt, \% }\end{array}$ & $\begin{array}{c}\text { Leaching } \\
\text { Efficiency Li, \% }\end{array}$ & Refs. \\
\hline PTSA-nH ${ }_{2} \mathrm{O} \cdot \mathrm{ChClDES}$ & - & 90 & 0.25 & 100.0 & 94.0 & 100.0 & {$[55]$} \\
PEG200/thiourea (2:1) & - & 160 & 24 & 60.2 & - & - & {$[56]$} \\
Reline (Urea-ChCl) & $4 \% \mathrm{H}_{2} \mathrm{O}$ & 160 & 24 & 43.0 & - & - & {$[57]$} \\
(ChCl:EG) & - & 180 & 24 & $29.6-32.0$ & 74.0 & 71.0 & {$[58]$} \\
Choline-Chloride-citric acid & $\begin{array}{c}\mathrm{Al}, \mathrm{Cu}, \\
35 \mathrm{wt.} \% \mathrm{H}_{2} \mathrm{O}\end{array}$ & 40 & 1 & 99.6 & 81.0 & 93.0 & {$[59]$} \\
\hline
\end{tabular}

Most leaching processes, at least for nickel laterites and sulfides, extract both cobalt, nickel and result in a mixed $\mathrm{Co} / \mathrm{Ni}$ solution that needs to be separated [60]. A favored 
industrial process for the selective solvent extraction of cobalt from nickel is the use of phosphinic acid derivatives, such as Cyanex 272. However, Cyanex 272 tends to extract impurities, such as $\mathrm{Cu}, \mathrm{Zn}, \mathrm{Fe}, \mathrm{Cd}, \mathrm{Ca}, \mathrm{Mg}$, and Mn along with cobalt [60], and thus there is a need for more selective processes. Table 4 highlights how IL can be used in $\mathrm{Co} / \mathrm{Ni}$ separation. Note that there is a study published in 2013 that used two mutually immiscible ionic liquids—one of the first examples of such experiments [61].

Table 4. Examples of IL used in Co/Ni separation.

\begin{tabular}{|c|c|c|c|c|c|}
\hline Year & Ionic Liquid & Aqueous Medium & Separation Factor & Mechanism & Refs. \\
\hline 2010 & [A336][CA-12] in toluene & Sulfate & 25 & Ion association & [62] \\
\hline 2012 & $\begin{array}{l}\text { Cyphos }^{\circledR} \text { IL 101, aka } \mathrm{P}_{66614} \mathrm{Cl} \\
\text { saturated with water }\end{array}$ & Chloride & 50,000 & Anion exchange & [63] \\
\hline 2013 & $\begin{array}{l}\text { Cyphos IL } 104 \text { aka, } \\
{\left[\mathrm{P}_{66614}\right]\left[\mathrm{R}_{2} \mathrm{POO}\right]} \\
\mathrm{R}=2,4,4 \text {-trimethylpentyl }\end{array}$ & {$\left[\mathrm{C}_{2} \operatorname{mim}\right] \mathrm{Cl}$} & 207 & Anion exchange & [61] \\
\hline 2014 & {$\left[\mathrm{P}_{44414}\right][\mathrm{Cl}]-\mathrm{NaCl}-\mathrm{H}_{2} \mathrm{O}$} & Chloride & $<500$ & Anion exchange & [64] \\
\hline
\end{tabular}

\subsection{Nickel and Manganese}

Cobalt, nickel, and manganese are also components of lithium battery cathodes. The next few studies have taken a more holistic approach to lithium-ion battery recycling, attempting to separate all potential critical metals from simulated end-of-life batteries. Othman et al. [65] created a feed solution consisting of $\mathrm{Cu}, \mathrm{Mn}, \mathrm{Ni}$, and $\mathrm{Li}$, as reflecting typical cathode material. Tetraoctylphosphonium oleate $\left[\mathrm{P}_{8888}\right][$ Oleate], a functionalized fatty-acid-based IL with selective extractive ability influenced by $\mathrm{pH}$, was chosen due to the hydrophobic nature of both the cation and anion.

The bulky nature of the oleate-ion means that even when deprotonated, the ion remains very hydrophobic, which prevents the loss of the anion to the aqueous phase, a common problem in IL chemistry. At $\mathrm{pH} 5$, cobalt, manganese and nickel were extracted with nearly $100 \%$ efficiency through interaction with the oleate ions, and Li was not extracted at all. At $\mathrm{pH}$ values lower than zero, $\mathrm{Co}$ and $\mathrm{Mn}$ maintained their high extraction efficiencies, but $\mathrm{Ni}$ was no longer extracted.

This phenomenon is due to the formation of tetrachloro-anion complexes in the presence of excess $\mathrm{Cl}^{-}$ions. $\mathrm{Mn}$ and $\mathrm{Co}$ were separated using mixed salt regeneration solutions, and $\mathrm{Ni}$ was selectively precipitated from $\mathrm{Li}$ in the form of $\mathrm{NiCO}_{3}$. Overall, $\left[\mathrm{P}_{8888}\right]$ [Oleate] successfully facilitated the separation and recovery of $\mathrm{Co}, \mathrm{Mn}, \mathrm{Ni}$, and $\mathrm{Li}$ from simulated $\mathrm{HCl}$-based Li-ion leachate [65]. Although this method was acidic and reagent intensive, it transformed a rather messy mixture of metals and separated them with one IL based on $\mathrm{pH}$ dependence. It would be of interest to more thoroughly understand the $\mathrm{pH}$ dependence of ILs as they present a better atom economy than a multi solventbased system.

Another IL based Mn, Co, Ni, Li separation system [66] involved the following: first, manganese extraction via $\mathrm{N}, \mathrm{N}, \mathrm{N}^{\prime}, \mathrm{N}^{\prime}$-tetra $(n$-octyl) diglycolamide (TODGA) dissolved in imidazolium-based ILS. TODGA is an extractant commonly used in metal recovery and has an affinity for trivalent metals. Next, cobalt removal using a phosphonium-based IL, such as $\left[\mathrm{P}_{66614}\right][\mathrm{Cl}]$. Lastly, nickel/lithium separation with a DES made from carboxylic acids and lidocain (DecA:Lid [2:1]). Although this process used significantly less acid than the previously mentioned process, it still required large quantities of solvents and extractants and needs optimization and compactization.

\section{Metals for Electronic Devices and Optics}

Indium, gallium, and germanium are used in technologies, including light-emitting diodes (LEDs), fiber optics, infrared optics, and solar cells. Indium and germanium are often grouped together due to their similar uses, and because both are recovered as byproducts from the same ore. Demand for these metals has increased in the past few years as new 
telecommunication networks compete to have the fastest transmission speeds. Indium is used mainly for production of tin-doped indium oxide used in flat-panel displays and touchscreens, as well as in the form of indium phosphide for lasers and receivers, used in fiber optic networks application [67].

Gallium Arsenide (GaAs) device consumption has also increased due to the telecommunications growth, as GaAs is used to manufacture integrated circuits and optoelectronic devices [43]. Germanium is mainly used in optics due to its transparency to part of the infrared electromagnetic spectrum, high refractive index, and low chromatic dispersion. Germanium also can catalyze the polymerization of PET resin without undesirable coloring. Figure 5 shows the different uses of germanium and indium [67].

A. Germanium

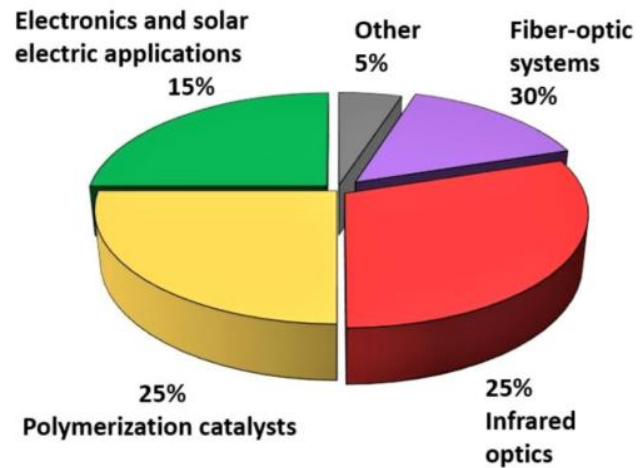

B. Indium

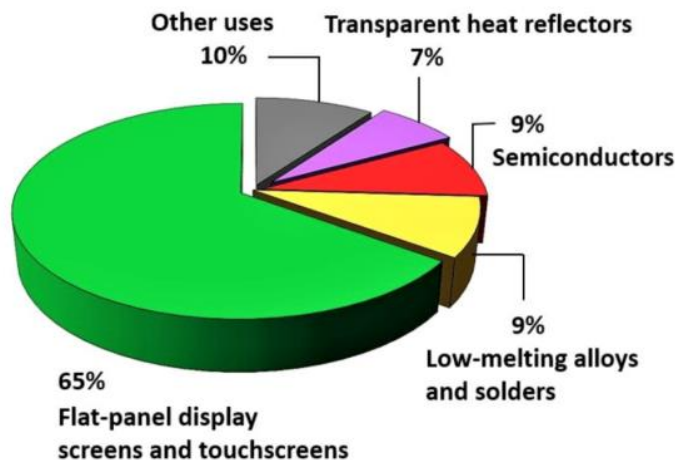

Figure 5. Pie charts showing major end uses of (A) germanium and (B) indium as a percentage of global consumption in 2012. Data from [67].

\subsection{Indium}

Some ILs studied for the leaching and extraction of In(III) from aqueous solution include Cyphos ${ }^{\circledR}$ IL 101 [68], Aliquat ${ }^{\circledR} 336$ [69], [A324H+][Cl-] in Solvesso 100 [70], and [Hbet][ $\left.\mathrm{Tf}_{2} \mathrm{~N}\right]$ in ascorbic acid [71]. The experiment using [Hbet][Tf $\left.{ }_{2} \mathrm{~N}\right]$ [71] was performed on crushed liquid crystal displays (LCDs). Ascorbic acid was added to decrease the distribution rate of iron and promote selective indium extraction. Overall, extraction of indium from this process reached up to $98.63 \%$.

Indium was also selectively extracted from $\mathrm{Ni}(\mathrm{II})$ and $\mathrm{Zn}(\mathrm{II})$, by tri-butyl-phosphate (TBP) in n-hexyl-trimethylammonium bis(trifluoromethylsulfonyl)amide [N1116][TFSA] and then recovered by direct electrodeposition of the loaded organic phase [72]. The aqueous solution consisted of Fe(II), Ni(II), Zn(II), In(III), and Sn(II) ions in H[TFSA]. Nitric acid was added to oxidize $\mathrm{Sn}(\mathrm{II}) / \mathrm{Sn}(\mathrm{IV})$ and Fe(II)/Fe(III), which were then precipitated as hydroxide and oxide, respectively.

TBP, a neutral extractant soluble in ILs, was contacted with the aqueous phase to extract indium via a cation exchange mechanism. The electrodeposition of $\left[\operatorname{In}(\mathrm{TBP})_{3}{ }^{3+}\right] / \operatorname{In}(0)$ under different potentiation conditions was then performed. The reduction peak at $-1.0 \mathrm{~V}$ was assigned at the $\left[\operatorname{In}(\mathrm{TBP})_{3}{ }^{3+}\right] / \operatorname{In}(0)$ couple and resulted in the electrodeposition of most pure In metal [72].

Binnemans' group recently published studies on the electrodeposition of indium from ILs. The electrochemical deposition of indium from aqueous solutions has the unfortunate consequences of simultaneously releasing hydrogen gas. Ionic liquids present a way to circumvent hydrogen evolution by offering a wider electrochemical window than water. In the case of electrodeposition from an IL, the IL acts as a liquid cathode, which is advantageous over solid cathode because liquid cathodes offer a constant electrode surface and promote more regular crystal growth. The electrodeposition of In in Cyphos IL 101 involved two steps: the reduction of $\operatorname{In}(\mathrm{III})$ to $\operatorname{In}(\mathrm{I})$ followed by the reduction of $\operatorname{In}(\mathrm{I})$ to $\operatorname{In}(0)$. The electrodeposition of $\mathrm{InCl}_{3}$ and $\operatorname{In}\left(\mathrm{Tf}_{2} \mathrm{~N}\right)_{3}$ in DME or PEG400 was also tested. A combination of these electrolytes seemed to form an electroactive complex [73]. 
Indium can be found in goethite residue from zinc production. However, indium is only present in small concentrations, which means other higher concentrated elements, such as iron, are often leached together with indium. Supported Ionic Liquid Phase (SILP) extractions have also been examined for recovery of indium, as well as germanium, from iron-rich solutions.

SILPs consists of a thin IL layer covalently anchored or impregnated onto a solid support, usually a porous resin. SILPs hold great potential for industrial scale operations due to the ease in which the solid phase can be separated from the aqueous phase at the completion of the reaction. Both indium and germanium were selectively recovered from iron rich solutions using Aliquat336- based ionic liquids impregnated on Amberlite XAD-16N, with $\mathrm{SF}_{I n / F e}$ equal to 5400 and $\mathrm{SF}_{\mathrm{Ge} / \mathrm{Fe}}$ equal to $34,400[69,74]$. Aliquat 336 is a commercial liquid anion exchanger that consists of a quaternary ammonium salt and is a popular choice for IL cations.

\subsection{Germanium}

As aforementioned, one of the main sources of Ge used in industrial processes is by-product from zinc ore processing. Another major source of Ge is coal fly ash from power plants. Coal ash can be leached with water; however, the resulting leachate contains many elements and germanium in the form of $\mathrm{GeO}_{2}$ and $\mathrm{GeS}_{2}$, therefore, solvent extraction is a popular method for separation [75]. Extraction agents Alamine 336, Aliquat 336, and Cynaex 923 have been used for Ge separation, with the aid of tartaric acid and oxalic acid complexing agents [76]. Aliquat 336 has also been used in conjugation with a flat sheet and hollow fiber supported ionic liquid membrane (HFSLM) system for selective germanium(IV) extraction [77].

Since 2016, at least 30\% of the germanium in the world has been provided through recycled germanium materials, such as electronic devices and optical fibers. According to Ruiz, Sola, and Palmerola the recycling efficiency for fiber-optics scrap is higher than $80 \%$ [78].

After extraction of germanium from end-of-life products, it can be reprocessed through electrodeposition, which not only guarantees a high purity but also the ability to form special structures, such as nanoparticles and nanowires (for semiconductors). One study reported the deposition of germanium from $\mathrm{GeCl}_{4}$ saturated [BMIM] $\left[\mathrm{PF}_{6}\right.$ ] onto gold [79] Another study reported electrochemical deposition gallium nanoparticles and germanium nanostructures from [EMIm] $\mathrm{Tf}_{2} \mathrm{~N}$ using pulsed laser assistance [80].

\subsection{Gallium}

Gallium can be found in semiconductors in the forms of $\mathrm{GaN}$ and GaAs, accompanied by InAs. Semiconductors and LEDs, despite containing valuable sources of gallium and indium, are often not recycled due to recycling difficulties. Plastic casings and dismantling small parts are examples of some challenges. Acid can be used to effectively leach semiconductors; however, the simultaneous formation of lethal arsine $\left(\mathrm{AsH}_{3}\right)$ gas poses a significant health and safety hazard.

ILs offer an alternative leaching method that is significantly safer. Trihalide ILs are capable of dissolving metals and alloys without the formation of any gases. van de Bossche et al. used $\left[\mathrm{P}_{44410}\right]\left[\mathrm{Br}_{3}\right]$ to demonstrate its effectiveness in leaching semiconductor compounds and real LEDs [81]. After the metals were saturated in the organic phase, Arsenic was stripped using $\mathrm{NaBr}$ salt, gallium was stripped with water, and indium was recovered using Cyphos 101 to form an indium(III) hydroxide precipitate. Unfortunately, GaN could not be dissolved through this process.

Gallium does not readily form minerals in which it is the major component; consequently, most gallium is recovered as a by-product from the processing of other raw materials. Like germanium, gallium can be found in zinc ore residue, coal ash, bauxite residues and iron mine tailings. Bauxite is the major ore from aluminum production. 
During the Bayer process, the bauxite is digested by sodium hydroxide, and aluminum is crystallized out.

The leftover Bayer leach liquor contains a mixed cocktail of gallium, vanadium, silica, residual ammonium, and other impurities. In the 1990s, the extraction of gallium with Kelex 100 was explored but determined to be impractically slow to be employed on an industrial scale. However, Raigual et al. recently studied the behavior of Kelex 100 in 1,2,3triazolium IL diluents [82].

ILs were superior to kerosene systems because they equilibrated faster, bonded to gallium stronger, and avoided the use of volatile and flammable organic solvents. At optimal conditions, 4-ethyl-5-methyl-1,3-dihexyl-1,2,3-triazolium bis(trifluoromethylsulfonyl)imide $[\mathrm{HHT} 23]\left[\mathrm{Tf}_{2} \mathrm{~N}\right]$ reached $\mathrm{Ga} / \mathrm{Al}$ distribution ratios as high as 1000 and yielded a pure gallium product. This process shows promise for industrial application, especially since it does not require decomposing the Bayer liquids before extraction.

Kinsmen et al. [83] attempted to recover gallium from iron mine tailings using methyltriocytlammonia [MTOA][I] (where [MTOA] = [A336]), which serves the dual purposed of reducing iron(III) to a less soluble state and extracting gallium. Using [MTOA][I] as a reductant and reactant proved to be operationally simple and cost effective. This experiment exemplifies Green Chemistry principles with environmentally viable reagents, a regenerable organic phase, and reduction of waste streams compared to traditional methods. [MTOA][I] was diluted in toluene and water was used as a stripping agent. The next steps would be using pure [MTOA][I] without a diluent as was proven possible in the experiment done with water saturated [HTOA] $\left[\mathrm{NO}_{3}\right]$ extraction of Pd mentioned earlier in this paper $[45,83]$.

\section{Rare Earth Elements (REE)}

Rare earth elements (REE) refer to the group of 17 elements-the lanthanides as well as Sc and Y-according to the International Union of Pure and Applied Chemistry. The REE are commonly divided into light rare earth elements (LREE), La-Sm, and the heavy rare earth elements (HREE), Eu-Lu. In today's world, REE are valued for their role in alternative power and energy saving applications. Despite not actually being rare, REE are often found in minimal concentrations, making them difficult to mine.

The United States imports substantial amount of their rare earth (RE) supply from China. Considering the importance of these minerals in technological and economic advancement, the U.S. is looking for increased domestic production and recovery of the REs from different sources to decrease supply chain vulnerability [84]. As mining rare earths from ore poses some significant environmental issues, much research is being conducted on the sustainable recycling potential of REs from waste.

Major RE-containing waste streams include pre-consumer manufacturing scraps/waste, end-of-life products, and industrial waste. Currently, only limited quantities of rare earths are being recycled from batteries, permanent magnets, and fluorescent lamps; however, these numbers are expected to grow as electronic waste is positioned to become the fasted growing waste stream in the world [85]. A comprehensive review of ILs used in RE recovery was published in 2017 and is summarized in Table 5.

A review [20] categorizes the ILs as non-functionalized or pure, mono-functional, or bifunctional. The pure ILs are often not effective metal extractants by themselves and are usually combined with known metal extractants like CMPO, Cyanex 923, HDEHP, or DODGAA, for successful extraction. Functionalized ILs or Task-specific ILs are created using anion derivatives of popular extractants paired with hydrophobic quaternary ammonium or phosphonium cations. The review also does a good job explaining common reaction mechanism encountered in IL solvent extraction, mainly anion or cation exchange [20]. 
Table 5. Some selective findings summarized in "Recovery of rare earth elements with ionic liquids" review [20].

\begin{tabular}{|c|c|c|c|c|c|}
\hline Extractant & Solvent/Diluent & Feed & Target Product & Mechanism & Refs. \\
\hline$\left[\mathrm{C}_{8} \mathrm{mim}\right]\left[\mathrm{PF}_{6}\right]$ & water & $\begin{array}{l}\text { Nitric acid solution } \\
\text { of lanthanides (III) } \\
\text { and thorium (IV) }\end{array}$ & Cerium(IV) & $\begin{array}{l}\text { Anion exchange } \\
\mathrm{KPF}_{6} \text { strippant }\end{array}$ & [86] \\
\hline $\mathrm{CMPO}$ & {$\left[\mathrm{C}_{4} \mathrm{mim}\right]\left[\mathrm{PF}_{6}\right]$} & $\begin{array}{l}\text { Nitric acid solution } \\
\text { of mixed salts }\end{array}$ & $\begin{array}{c}\mathrm{Ce}(\mathrm{III}), \mathrm{Eu}(\mathrm{III}), \\
\text { Y(III) }\end{array}$ & Cation exchange & [87] \\
\hline Cyanex 923 & $\begin{array}{c}{\left[\mathrm{C}_{4} \operatorname{mim}\right]\left[\mathrm{Tf}_{2} \mathrm{~N}\right]} \\
{\left[\mathrm{N}_{1444}\right]\left[\mathrm{Tf}_{2} \mathrm{~N}\right]} \\
{\left[\mathrm{C}_{10} \mathrm{mim}\right]\left[\mathrm{Tf}_{2} \mathrm{~N}\right]} \\
{\left[\mathrm{P}_{66614}\right]\left[\mathrm{Tf}_{2} \mathrm{~N}\right]} \\
{\left[\mathrm{N}_{1888}\right]\left[\mathrm{Tf}_{2} \mathrm{~N}\right]}\end{array}$ & $\begin{array}{c}\mathrm{Nd} \text { in nitric acids } \\
\text { solution }\end{array}$ & $\mathrm{Nd}(\mathrm{III})$ & Cation exchange & [88] \\
\hline HDEHP & $\begin{array}{l}{[\mathrm{Cnmim}]\left[\mathrm{Tf}_{2} \mathrm{~N}\right]} \\
{[\mathrm{C} n \mathrm{mim}][\mathrm{BETI}]} \\
{[\mathrm{C} 4 \mathrm{mPy}]\left[\mathrm{Tf}_{2} \mathrm{~N}\right]}\end{array}$ & $\begin{array}{l}\text { Lanthanide ions in } \\
\text { glycolic acid or } \\
\text { citric acid }\end{array}$ & REE & Cation exchange & [89] \\
\hline Htta & {$[\mathrm{C} 4 \mathrm{mim}]\left[\mathrm{Tf}_{2} \mathrm{~N}\right]$} & & $\mathrm{Nd}(\mathrm{III}), \mathrm{Eu}(\mathrm{III})$ & $\begin{array}{l}\text { Anion exchange } \\
\text { HTfN strip }\end{array}$ & [90] \\
\hline PC-88A & $\left([\mathrm{C} n \operatorname{mim}]\left[\mathrm{Tf}_{2} \mathrm{~N}\right], n=8,12\right)$ & & $\begin{array}{c}\mathrm{La}(\mathrm{III}), \mathrm{Ce}(\mathrm{III}), \\
\mathrm{Eu}(\mathrm{III}), \text { and Y(III) }\end{array}$ & proton exchange & {$[91]$} \\
\hline DODGAA & $\left.[\mathrm{C} n \operatorname{mim}]\left[\mathrm{Tf}_{2} \mathrm{~N}\right] n=4,8,12\right)$ & $\mathrm{Y}^{3+}, \mathrm{Eu}^{3+}, \mathrm{Zn}^{2+}$ & Y(III), Eu(III) & Proton exchange & [92] \\
\hline$[$ Hbet $]\left[\mathrm{Tf}_{2} \mathrm{~N}\right]$ & water & $\begin{array}{l}\text { Roasted NdFeB } \\
\text { magnets }\end{array}$ & $\mathrm{REO}_{\mathrm{n}}$ & $\begin{array}{c}\text { Release of protons } \\
\text { by [Hbet]+ }\end{array}$ & [93] \\
\hline $\begin{array}{l}\text { [A366][CA-12] } \\
\text { [A336][CA-100] }\end{array}$ & $n$-heptane & Chloride medium & $\mathrm{La}(\mathrm{III})$ & & [94] \\
\hline [A336][DGA] & {$[\mathrm{A} 336]\left[\mathrm{NO}_{3}\right]$} & $\begin{array}{l}\text { Nitric acid } \\
\text { medium }\end{array}$ & $\mathrm{Nd}(\mathrm{III})$ & & [95] \\
\hline $\begin{array}{l}\text { [A336][DHDGA] } \\
\text { [OcGBOEt][Br] }\end{array}$ & $\begin{array}{l}\text { Hexane, toluene, } \\
\text { chloroform }\end{array}$ & Nitrate feed & $\begin{array}{c}\mathrm{La}, \mathrm{Pr}, \mathrm{Nd}, \mathrm{Sm}, \mathrm{Eu}, \\
\mathrm{Tb}, \mathrm{Dy}, \mathrm{Y}, \mathrm{Er}\end{array}$ & Ion association & [96] \\
\hline $\begin{array}{l}{\left[\mathrm{N}_{2222}\right][\mathrm{EHEHP}]} \\
{\left[\mathrm{N}_{2222}\right][\mathrm{DEHP}]} \\
{\left[\mathrm{N}_{4444}\right][\mathrm{DEHP}]} \\
{\left[\mathrm{N}_{6666}\right][\mathrm{DEHP}]} \\
{\left[\mathrm{N}_{8888}\right][\mathrm{DEHP}]}\end{array}$ & heptane & $\begin{array}{l}\text { REE chloride } \\
\text { solution }\end{array}$ & RE & & [97] \\
\hline [TOMA][DEHP] & $\begin{array}{c}{[\mathrm{C} n \operatorname{mim}]\left[\mathrm{Tf}_{2} \mathrm{~N}\right], n=4,6} \\
8,10 \\
{[\mathrm{C} n \operatorname{mim}][\mathrm{BETI}], n=4,6} \\
8,10)\end{array}$ & RE solution & $\mathrm{RE}$ & & [98] \\
\hline $\begin{array}{l}{\left[\mathrm{PEGm}(\mathrm{mim})_{2}\right]} \\
{\left[\mathrm{Tf}_{2} \mathrm{~N}_{2}(\mathrm{~m}=200\right.} \\
400,600)\end{array}$ & water & Nitrate feed & $\begin{array}{l}\text { Sc, Y, La-Nd, Sm, } \\
\text { Gd, Dy, Ho, Yb, Lu }\end{array}$ & $\begin{array}{c}\text { Ion pair } \\
\text { association }\end{array}$ & [99] \\
\hline
\end{tabular}

$\mathrm{CMPO} \equiv$ carbamoylmethylphosphine oxide, HDEHP $\equiv$ Di-(2-ethylhexyl)phosphoric acid, Htta $\equiv 2$ thenoyltrifluoroacetone, $\mathrm{PC}-88 \mathrm{~A} \equiv$ 2-ethylhexyl phosphonic acid mono-2-ethylhexyl ester, DODGAA $\equiv \mathrm{N}, \mathrm{N}$ dioctyldiglycolamic acid.

\subsection{Rare Earths from Urban Waste}

\subsubsection{Nd-Fe-B Magnets}

$\mathrm{Nd}-\mathrm{Fe}-\mathrm{B}$ magnets are the most common type of RE magnets and have a wide range of applications and they can be full density (typically sintered) or bonded with polymer or resins. Most recycling research works focus on sintered magnets due to the higher RE content and chemical simplicity, although the Binnemans groups recently published a study on bonded Nd-Fe-B magnet recycling (Figure 6) with ionic liquids [100].

Pre-treatment of Nd-Fe-B magnet prior to elemental recovery can include crushing, milling, shredding, decrepitation, and roasting. Oxidative roasting has been proven to improve the selectivity and dissolution rate of neodymium during subsequent leaching, both with hydrometallurgical methods and ILs [101]. After pretreatment, the magnets can be leached with acid, ionic liquids, or, in a groundbreaking simple and green discovery, with copper salts [102]. Leaching is rarely completely selective, and thus another extraction 
step is needed. That is where all the studies on recovery RE from acidic media with ILs come into play.

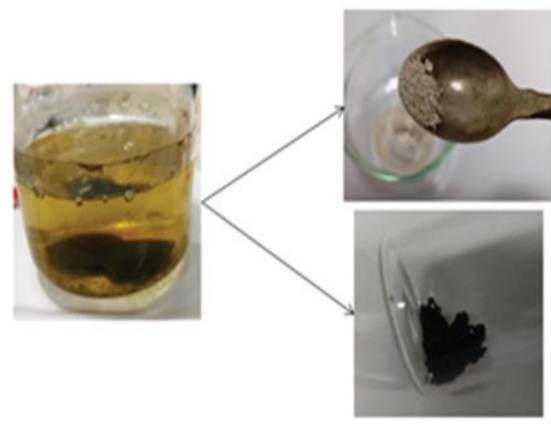

(a)
Solvent

$\left[\mathrm{P}_{4442}\right]\left[\mathrm{Et}_{2} \mathrm{PO} 4\right]$

[ $\left.\mathrm{C}_{2} \mathrm{MIM}\right]\left[\mathrm{CH}_{3} \mathrm{COO}\right]$

$\left[\mathrm{C}_{2} \mathrm{mim}\right][\mathrm{Cl}]$

$\left[\mathrm{C}_{8} \operatorname{mim}\right][\mathrm{Cl}]$

Cyphos IL 101

Aliquat 336

[ $\left.\mathrm{C}_{4} \mathrm{mim}\right]\left[\mathrm{Tf}_{2} \mathrm{~N}\right]$

$\mathrm{N}$-methylpyrrolidone
Dissolution

Yes

Yes

Yes

Yes

Yes

Yes

Yes

Yes

(b)

Figure 6. (a) Left: Dissolution of polyamide 12 (PA12) in $\left[\mathrm{P}_{4442}\right]\left[\mathrm{Et}_{2} \mathrm{PO}_{4}\right]$; the very fine magnet powder is collected at the bottom with the help of a magnet. Upper right: Isolation of PA12 powder after precipitation by addition of water. Lower right: Isolation of magnet powder that is still coated by a polysiloxane-polyether layer. (b) Dissolution experiments on polyamide 12 (PA12) in different solvents. Reproduced from [100] with permission from the Royal Society of Chemistry.

A topic of recent interest is the recovery of dysprosium (Dy) from Nd-Fe-B magnets. Dysprosium is added to the magnet to increase resistance to demagnetization and enhance high temperature performance. Dysprosium containing magnets can be found in car motors or wind turbines. Separating $\mathrm{Nd}$ and Dy is very challenging due to the similarity in chemical properties. Riano et al. reports testing IL trihexyl(tetradecyl)phosphonium thiocyanate [C101][SCN] in conjugation with Cyanex 923 to separate Nd(III) and Dy(III) from highly concentrated chloride solutions [103].

However, after experimentation, Dy/Nd distribution ratios for the IL system did not exceed 3.34, which was about half that of Cyanex 923 in toluene. In a slightly different but effective solvometallurgical approach, Prodius et al., used molten salts as leaching agents for the selective solubilization of Dy, with extraction efficiencies up to 68\% [104]. With a little more research, ILs could be a big contender for developing novel and green Dy and Nd separation techniques.

\subsubsection{Samarium-Cobalt Magnets}

The other variant of magnet containing REE is the samarium-cobalt magnet, which is characteristic for better resistance to demagnetization and higher costs than Nd-Fe-B. Unlike Nd-Fe-B magnets, the limiting ingredient in Sm-Co magnets is not the rare earth, samarium, but rather cobalt, of which the limited supply is primarily funneled towards lithium-ion batteries.

Although Sm-Co magnets are not as widely produced as Nd-Fe-B magnets, they still make a great secondary source for cobalt and samarium. A group at KU Leuven in Belgium reported a solvometallurical route for the recovery of $\mathrm{Sm}, \mathrm{Co}, \mathrm{Cu}$, and Fe from Sm-Co magnets. After leaching the magnet powder with $\mathrm{HCl}$ in ethylene glycol, $\mathrm{Co}, \mathrm{Cu}$, and $\mathrm{Fe}$ were extracted by Aliquat 336, of which extraction efficiencies for such had been studied extensively in a previous paper [105]. Samarium was separated from the transition metals via extraction with Cyanex 272. Cobalt was recovered by stripping with $\mathrm{HCl}$, and $\mathrm{Cu}$ and Fe were recovered by stripping with ammonia. The recovered metals were found to have the following purity: $99.4 \mathrm{wt}$.\% for Sm, $98.3 \mathrm{wt}$ \% for cobalt and $100.0 \mathrm{wt}$ \% for iron and copper [106].

\subsubsection{Fluorescent Lamps}

End-of-Life fluorescent lamps are also a secondary source for heavy rare earth elements, such as europium, terbium, and yttrium. A couple of solvometallurical routes for the 
valorization of REE phosphors have been reported. In 2015, Dupont and Binnemans demonstrated that [Hbet][ $\left.\mathrm{Tf}_{2} \mathrm{~N}\right](<5 \mathrm{wt} . \%$ of water) has good selectivity for yttrium(III) oxide (YOX) from the halophosphate phosphor (HALO, $\left.(\mathrm{Sr}, \mathrm{Ca})_{10}\left(\mathrm{PO}_{4}\right)_{6}(\mathrm{Cl}, \mathrm{F})_{2}: \mathrm{Sb}^{3+}, \mathrm{Mn}^{2+}\right)$ (Figure 7) [107]. This selectivity eliminates considerable amounts of acid consumed for HALO dissolution.

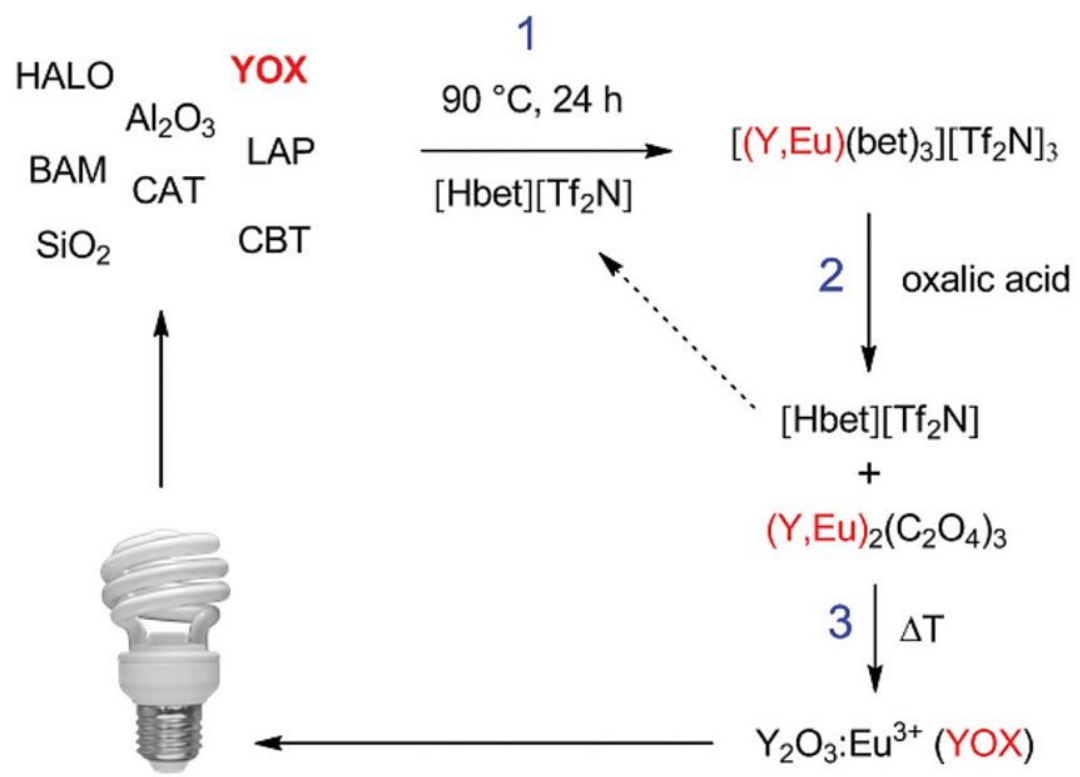

Figure 7. Summary of the suggested recycling process for lamp phosphor wastes. Phase 1: Dissolution of $\mathrm{Y}_{2} \mathrm{O}_{3}$; Phase 2: Regeneration of ionic liquid (stripping); and Phase 3: Conversion to yttrium(III) oxide. Reproduced from [107] with permission from the Royal Society of Chemistry.

In a follow-up study [108], the same lab group tested DESs for the recovery of REE from lamp phosphor waste. After testing a couple different phosphors with five different choline chloride-based DESs, it was determined that the best performing DES was levulinic acidcholine chloride (LevA-ChCl), which showed similar leaching behavior to pure clavulanic acid. In addition to being a good leaching agent, levulinic acid can be obtained by the conversion of sugars, a highly renewable and affordable source. In a comparison study, (LevA-ChCl) was found to be as efficient and selective as [Hbet][Tf $2 \mathrm{~N}]$ [108].

\subsection{Lab-Test Separations of Rare Earths}

As with the other metals discussed in previous chapters, ILs have been used to perform numerous functions involving REEs. The electrodeposition of most rare earths (RE) has been studied for ammonium-, pyrrolidinium, and imidazolium-based ILs. Notably, neodymium electrodeposition has only been proven successful in phosphonium-based ILs [109]. DES [110-112], SILP [113-115], and liquid-liquid extraction [116,117] have also been studied for RE extraction.

However, to avoid repetitiveness due to the massive amount of literature on RE solvent extraction, this review will not go into extensive detail on these methods. In the spirit of greener chemistry, Li et al. synthesized functionalized ILs from common vegetable oils for rare earth recovery [118]. Peanut oil, rapeseed oil, sunflower seed oil, and flaxseed oil were selected as fatty acid precursors to oleate, which has previously been proven to extract metals.

The oils were paired with the [A336] cation for its excellent hydrophobicity and subsequently compared with a naphthenic acid (NA) IL, [N1888][NA], since NA is used in common industrial practices. The results showed that although [N1888][NA] consistently had the highest extraction efficiency, the fatty acid based ILs all showed great potential. This study has proven the possibility of accessibility, biocompatibility, and sustainability for metal extraction and it is worth expanding upon in the future. 


\section{Actinides}

The actinides mainly found in nuclear processes are americium, curium, neptunium, uranium, and plutonium. Plutonium and uranium are considered major actinides, since they are the main fuel in nuclear reactors, and the rest are considered minor actinides. The minor actinides account for most of the radiotoxicity of spent-fuel waste. A few processes been developed for reprocessing fuel, such as those in the list below along with their main extractant [119]:

- PUREX (Plutonium/Uranium extraction), TBP.

- TRUEX (Transuranic extraction) CMPO and TBP.

- DIAMEX (Diamide extraction) DGA.

- $\quad$ SANEX (Selective Actinide Extraction), N-heterocyclic ligands.

- TALSPEAK (Trivalent Actinide Lanthanide Separations by Phosphorus-reagent Extraction from Aqueous Complexes), HDEHP, DTPA.

- $\quad$ AIROX (Atomics International Reduction Oxidation).

- OREOX (Oxidation and Reduction of Oxide fuel).

During reprocessing, $\mathrm{Pu}$ and $\mathrm{U}$ are partitioned, (isolated from other elements including lanthanides), transmuted, and added back into the fuel cycle. The leftover materials, fission products, and minor actinides, can then be disposed of as high-level waste or recycled. Since nuclear fuel is becoming more popular as a green transition energy from fossil-based to zero-carbon, due to its high fuel/waste ratio and lack of greenhouse gas emission, major discussions are being had about whether spent nuclear fuel should be recycled. The open/closed fuel cycle conversation asks to what extent the present generation should take on the risks of handling and reprocessing nuclear fuel instead of leaving it for the future generation; it brings about the topic of intergenerational justice [120].

There are already good reviews regarding f-metal extractions and integration of ILs [21,121]. The most common types of f-metal extractants include organophosphorus compounds (TBP, Trioctylphosphine oxide, CMPO), amides (DGA, maloamides) and sulfoxides. To tweak or enhance extraction, these extractants have been diluted in IL, grafted onto ILS, or grafted onto macrocycles, such as calix[n]arenes, pillar[n]arenes, and crown ethers.

Until recently, there were very few cases reported in which the IL had extraction abilities without the use of an extractant or functionalization. Most of the literature on actinide extraction focuses on forming novel multidentate ligands for selective binding and complexation or improvement of existing extractant through functionalization and solvation. It has been found that replacing traditional organic solvents with ILs proved to improve extraction of actinides by three to four fold in many cases.

\subsection{Major Actinide Partitioning}

PUREX involves the dissolution of spent fuels in nitric acid followed by selective metal extraction using TBP into an organic phase of kerosene or dodecane. However, TBP has relatively high solubilities in water $/ \mathrm{HNO}_{3}$ solutions and its tendency toward third phase formation makes it a less than desirable candidate for large-scale extraction. A research group [122] synthesized 1-octyl-1-methylmorpholinium octylphosphite [Mor 1 -8][OP]—an IL that acts in its pure form as both the organic phase and extracting agent.

Using [Mor $\left.{ }_{1-8}\right][\mathrm{OP}]$ resulted in distribution ratios higher than 600 , which is much higher than the those found using TBP in the original PUREX method and extraction yields over $98 \%$ with only 20 min of equilibration time. This study focused on extracting $\mathrm{UO}_{2}{ }^{2+}$ ions from a pot of transition metal cations $\left(\mathrm{Cu}^{2+}, \mathrm{Fe}^{3+}, \mathrm{Ni}^{2+}, \mathrm{Co}^{2+}, \mathrm{Zn}^{2+}\right.$ and $\left.\mathrm{Cd}^{2+}\right)$. It was also tested pure phosphonate anion-based IL with long alkyl chains on mixed actinide solutions [122,123].

Another use of ILs that, in our opinion, is vastly understudied, is the selective solubilization of metal compounds/complexes in ILs. Unlike liquid-liquid extraction, this method does not rely on an extractant or salting out effects and in some cases, can significantly reduce the amount of waste produced, compared to typical liquid-liquid solvent extractions. An example of this is explored by Fan et al. [18], in the selective leaching 
of fission products, namely lanthanide oxides, from uranium oxide using the carboxylfunctionalized IL [Hbet][Tf $\left.{ }_{2} \mathrm{~N}\right]$.

As aforementioned, [Hbet][Tf $\left.{ }_{2} \mathrm{~N}\right]$ can dissolve RE oxides and transition metal oxides. As elements with the ability to absorb neutrons, the lanthanides are considered neutron poison and need to be removed before the major actinides can be reprocessed. In this case, [Hbet][Tf $\left.{ }_{2} \mathrm{~N}\right]$ was used to selectively dissolve the fission products, around $3.6 \%$ of spent nuclear fuel, from the $\mathrm{UO}_{2}$ matrix, which could then be recovered and regenerated as new nuclear fuel [18,124] (Figure 8).

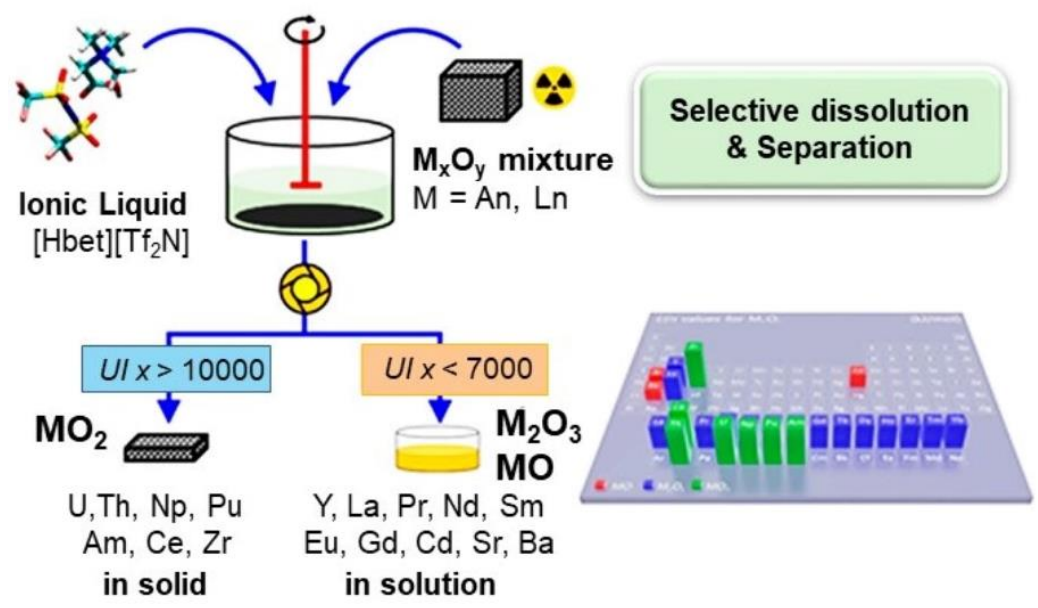

Figure 8. Schematic representation of selective dissolution and separation of fission products with help of carboxyl-functionalized ionic liquid, [Hbet][Tf $\left.{ }_{2} \mathrm{~N}\right]$. "Reprinted (adapted) with permission from Fan, F. L.; Qin, Z.; Cao, S. W.; Tan, C. M.; Huang, Q. G.; Chen, D. S.; Wang, J. R.; Yin, X. J.; Xu, C.; Feng, X. G. Highly Efficient and Selective Dissolution Separation of Fission Products by an Ionic Liquid [Hbet][Tf $\left.{ }_{2} \mathrm{~N}\right]$ : A New Approach to Spent Nuclear Fuel Recycling. Inorg. Chem. 2019, 58 (1), 603-609. Copyright 2019 American Chemical Society.

More specifically, water saturated [Hbet] $\left[\mathrm{Tf}_{2} \mathrm{~N}\right]$ was used to solubilize $\mathrm{M}_{2} \mathrm{O}_{3}$ compounds and had almost no solvation effect on $\mathrm{MO}_{2}$-type metal oxides, such as $\mathrm{AcO}_{2}\left(\mathrm{UO}_{2}\right.$, $\mathrm{NpO}_{2}, \mathrm{PuO}_{2}$, and $\mathrm{AmO}_{2}$ ), $\mathrm{ThO}_{2}, \mathrm{ZrO}_{2}$, and $\mathrm{CeO}_{2}$. [Hbet][Tf $\left.2 \mathrm{~N}\right]$ was stripped and regenerated with $\mathrm{HCl}$ and could be reused with only slightly decreased efficiency. Compared to the PUREX process, which involves dissolving large amounts of spent nuclear fuel in concentrated acid, the described process is much more environmentally friendly, highly efficient, and enhances proliferation resistance.

A large difference in the dissolution behavior of the uranium oxides in carboxylicfunctionalized IL, [Hbet][Tf $\left.{ }_{2} \mathrm{~N}\right]$ was demonstrated. The dissolution of uranium(VI) oxide was very rapid and resulted in saturation solubility of $15 \mathrm{wt} . \%$ at $0{ }^{\circ} \mathrm{C}$. Further possibility was reported for separating $\mathrm{UO}_{2}$ from the mixture with $\mathrm{U}_{3} \mathrm{O}_{8}$ by increasing the temperature of dissolution up to $100^{\circ} \mathrm{C}$ [125].

\subsection{Minor Actinide Separation}

The minor actinides, $\mathrm{Np}, \mathrm{Am}$, and $\mathrm{Cm}$ are responsible for most of the radiotoxicity of spent nuclear fuels. Therefore, there are ongoing efforts to separate the minor actinides from the major and from the lanthanides. In TALSPEAK, the extractant diethylenetriamine pentaacetate (DTPA) preferentially binds to actinides ions, presumably because the slightly softer Lewis acidic character of the actinides favors binding to the soft-donor amine group [126]. The aqueous is then contacted with an organic phase, which can be an IL [127].

Modifications to the PUREX process allow for feasible separation of Neptunium, with waste streams of Am, Cm, and Ln [128]. For the optimal recycling efficiency of waste cycles, americium needs to be removed as it contributes to the long-term heat load of the final waste. In other words, it is better for the environment to reuse americium than put it into the ground with other high-level nuclear waste products. Furthermore, recycled americium 
can potentially be used as fuel in thermal reactors or as an alternative to rocket fuel. The methods for Am/Cm separation fall into three major categories: selective oxidation of Am(III), the use of two ligands with opposite solubility and selectivity with respect to Am(III) and Cm(III), and size-based separation [129].

While there is some literature regarding Am/Eu separation using ILs, there appears to be no experiments done that utilize ILs for Am/Cu separation, and the few publish papers report complicated systems yielding low separation factors [129,130]. However, this is definitely an area worth exploring, especially if there are rapid developments in the space exploration industry [131].

Overall, the outlook for ILs in nuclear waste processing looks promising. Their ability to enhance extraction efficiency compared to the popularly used n-dodecane and relative radiolytic stability make them ideal. ILs with aromatic rings, which can absorb energy, are especially stable in radioactive environments [21]. Higher extraction efficiencies mean less solvent is needed; reducing waste volume and the easily tweakable nature of IL give more creative potential and adaptability to the separation process in general.

\section{Variation of Ionic Liquids: Deep Eutectic Solvents (DESs)}

DESs are often recognized as a class of ILs because they share many of the same general characteristics, including low volatility, high thermal stabilities, and low vapor pressures. However, compared to other types of ILs, DESs are typically inexpensive, biodegradable, nontoxic, and more accessible from the preparation perspective [132].

A DES is characterized by a significant depression in melting point compared to its constituent components, allowing the formation of liquid solvents from solid compounds, thus increasing the number of potential candidates to use in solvent design and formulation. This point, combined with the fact that the DES precursors could be chosen among nontoxic compounds, makes DES a promising solvents. Consequently, their physical-chemical properties have been intensively studied in the past decade [132].

DESs have many advanced applications, such as separations, gas capture, power systems, batteries technologies, biocatalysis, pharmaceuticals, organic chemistry, and ongoing researches overlap each other in many areas. One of the first focuses that ignited interest in DES as a class of solvents was for metallurgical applications including modern recycling efforts.

Xiao et al. investigated the various guanidine-based DESs and their selective leaching of REE from Nd-Fe-B magnets (Figure 9) [111]. The guanidine hydrochloride-lactic acid (GUA-LAC) DES demonstrated the highest separation factor $(>1300)$ between $\mathrm{Nd}$ and Fe. The viscosity of this type of DES at $50{ }^{\circ} \mathrm{C}$ was $36 \mathrm{cP}$, which was comparable to many common organic solvents.

There is an interesting study [133] describing to the comprehensive recovery of waste SmCo magnets with the help of hydrophobic DESs based on dodecanol (Dodec), tri-noctylphosphine oxide (TOPO), and decanoic acid (DA):lauric acid (LA) (2:1). The first two DESs was used to selectively extract Fe(III) and Sm(III) from the Sm-Co magnets leachate, and the third DES was used for Co and $\mathrm{Cu}$ separations. Finally, Co(II) and Sm(III) were completely separated (99\% recovery rate) with high purity product $(98.5 \%+)$.

In order to determine the effect of the leaching behavior of choline chloride-based deep eutectic solvents on the selective separation of In and Sn from an oxide flue dust material, Zürner and Frisch investigated three leaching agents: Ethaline $(\mathrm{ChCl}+$ ethylene glycol, 1:2), Reline ( $\mathrm{ChCl}+$ urea, 1:2), and Oxaline ( $\mathrm{ChCl}+$ oxalic acid dihydrate, 1:1) [134]. Oxaline was found to be the most efficient lixiviant, mostly due to the high chloride and oxalate concentration $(4.5 \mathrm{~mol} / \mathrm{L})$, which prevented coprecipitation of Fe and may have a significant influence on the stability of indium complexes in solution. 
(a)
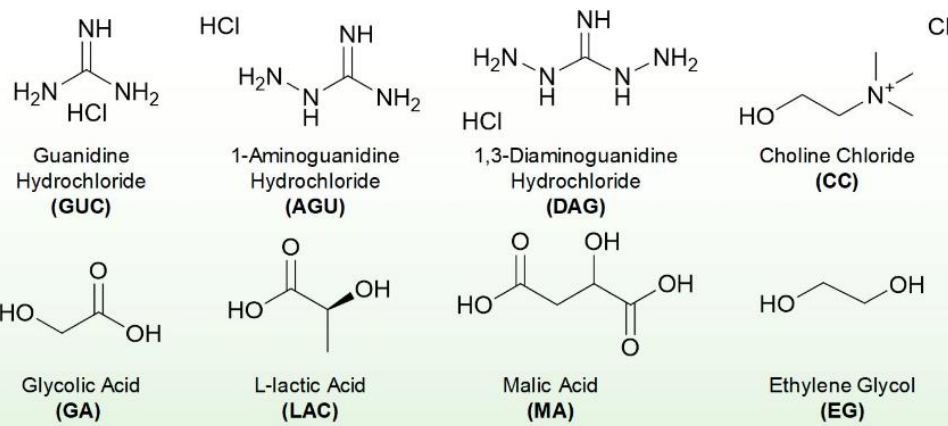

(CC)

(b)

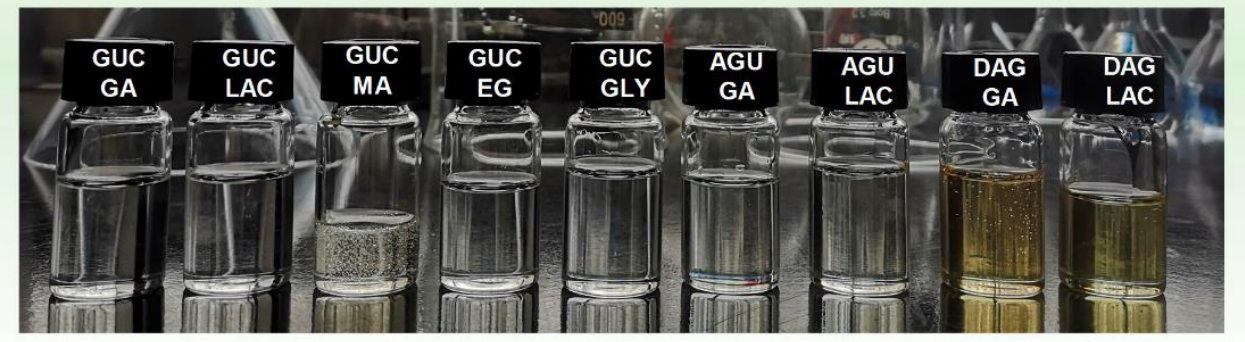

(c)

\begin{tabular}{cccccccccc}
\hline DES & $\begin{array}{c}\text { GUC- } \\
\text { GA }\end{array}$ & $\begin{array}{c}\text { GUC- } \\
\text { LAC }\end{array}$ & $\begin{array}{c}\text { GUC- } \\
\text { MA }\end{array}$ & $\begin{array}{c}\text { GUC- } \\
\text { EG }\end{array}$ & $\begin{array}{c}\text { GUC- } \\
\text { GLY }\end{array}$ & $\begin{array}{c}\text { AGU- } \\
\text { GA }\end{array}$ & $\begin{array}{c}\text { AGU- } \\
\text { LAC }\end{array}$ & $\begin{array}{c}\text { DAG- } \\
\text { GA }\end{array}$ & $\begin{array}{c}\text { DAG- } \\
\text { LAC }\end{array}$ \\
\hline $\mathrm{T}_{\mathrm{g}} /^{\circ} \mathrm{C}$ & -67.9 & -65.7 & -41.5 & -85.2 & -73.8 & -44.9 & -46.4 & 2.7 & -33.2 \\
$\mathrm{~T}_{\text {onset }}{ }^{\circ} \mathrm{C}$ & 108.6 & 112.9 & 183.1 & 129.1 & 205.4 & 176.1 & 137.2 & 181.9 & 177.1 \\
$\mathrm{~V}_{25} / \mathrm{cP}$ & 147.0 & 156.8 & 183694.9 & 22.7 & 353.5 & 2944.0 & 1824.7 & 50927.8 & 33854.0 \\
\hline
\end{tabular}

Figure 9. (a) Chemical structures of HBA (hydrogen-bond acceptor) and HBD (hydrogen-bond donor) molecules used in this work, (b) photograph of prepared DESs, and (c) glass transition temperature $\left(\mathrm{T}_{\mathrm{g}},{ }^{\circ} \mathrm{C}\right)$, onset decomposition temperature $\left(\mathrm{T}_{\mathrm{onset}},{ }^{\circ} \mathrm{C}\right)$, and viscosity $(\gamma)$ at $25{ }^{\circ} \mathrm{C}$ of guanidine-based DESs. "Reprinted (adapted) with permission from Liu, C.; Yan, Q.; Zhang, X.; Lei, L.; Xiao, C. Efficient Recovery of End-of-Life NdFeB Permanent Magnets by Selective Leaching with Deep Eutectic Solvents. Environ. Sci. Technol. 2020, 54, 16, 10370-10379. Copyright 2020 American Chemical Society.

Exponentially increasing lithium-ion batteries (LIB) production request an alternative to conventional methods of recycling and reclaiming strategic metals from the end-of-life materials. Babu, Ajayan et al. proposed a method of valuable metal extractions ( $>90 \%$ efficiency) from various chemistries, including lithium cobalt(III) oxide and lithium nickel manganese cobalt oxide [58].

Starting with disassembly of the LIB, cathode waste material was inserted into a choline chloride and ethylene glycol DES (ChCl:EG), which was then stirred and heated at $180{ }^{\circ} \mathrm{C}$. The resulting leaching efficiency was as high as $99.3 \%$. Temperature and time were crucial in controlling the strength of the metal extractions, with oxide dissolution being favored by extended experiments at relatively high temperatures.

In conclusion, environmentally friendly DESs not only present an opportunity to change the manner we use the waste as a source of critical metals but also motivate the search of new standards for their sustainable recycling.

\section{Conclusions}

Ionic liquids, particularly functionalized ILs and DESs, tend to have high viscosities compared to traditional organic solvents, which can have a significant impact on the reaction rate. However, the tunable nature of ILs allows scientists to design around this issue. Research into the specific properties of ILs is ongoing and is essential for the successful implementation of IL systems. 
Yu et al. analyzed the effect of IL ion components on viscosity and concluded that the viscosity values of the ILs with different cations follow the order: $[\mathrm{im}]^{+}<$[py $^{+}<$[pyr $^{+}<$ $[\mathrm{ox}]^{+}<$[pip $^{+}<[\mathrm{mo}]^{+}$, and cations with nonaromatic shapes or longer alkyl chains meant higher viscosity. For anions, the order was $[\mathrm{DCA}]^{-}<\left[\mathrm{NTf}_{2}\right]^{-}<[\mathrm{TfO}]^{-}<\left[\mathrm{BF}_{4}\right]^{-}<\left[\mathrm{PF}_{6}\right]^{-}$ $<$ [OAc $^{-}$[135]. In addition to selecting less viscous components, ILs can also be diluted in water, organic solvents, and other ILs.

ILs are touted as a more environmentally benign alternative to traditional volatile organic solvents (VOC) due to their lower vapor pressures. However, studies on IL toxicity are still being conducted, and it is important to obtain the full picture. There is little concern for ILs causing air pollution; however, there is some concern regarding the effects of ILs on soil and water environments. As there are so many possible combinations of cations and anions that can form ILs, the potential toxicity can vary widely.

Models based on quantitative structure-property/activity relationships (QSPR/QSAR) are being used to find correlations between IL physicochemical properties and toxicity and have been successful in making predictions about the properties of ILs. According to these datasets, longer alkyl sidechains in cations increased the toxicity of the IL and that $\left[\mathrm{NTf}_{2}\right]^{-}$ has an important influence on the toxicity [136].

Another interesting aspect to consider is the impact of quaternary ammonium compounds (QAC) on the environment. Since the beginning of the COVID-19 pandemic, world-wide increases in use of disinfectant chemicals has led to more environmental exposure to these compounds. QAC are biologically active chemicals, and thus their potential environmental impact, especially in aquatic environments, is currently a major focus of study. It is unclear what the results of these studies will be and how consumer trends will change in the future; however, potential regulations on QAC could significantly impact their use in ILs [137].

ILs are currently more expensive than traditional VOC solvents because the purification of highly charged ions is a cost intensive process [138]. However, increasing regulations on VOC have been resulting in increasing prices. The bis(trifluoromethylsulfonyl)imide $\left[\mathrm{NTf}_{2}\right]^{-}$anion, although very popular for its ability to produce low viscosity ILs, is a bit costly. However, ILs are ideally used in a way that they are regenerable or recyclable, which cuts down on cost significantly. According to Wang et al. "IL based REE extraction processes show promise in terms of economic feasibility" [20].

The bottom line is that more research needs to be done to fully understand ILs and successfully create efficient, green extraction systems. Understanding the reaction mechanisms and kinetics of IL can be especially helpful in preventing aqueous phase contamination and selecting regenerable ILs. Furthermore, there needs to be more clarification of stripping methods as most studies mainly focus on IL extraction ability rather than actual metal recovery.

Due to their multitude and unique tunable characteristic, ILs and DESs are perfect for a wide range of applications that are still being explored. Urban mining and electronic waste recycling are rapidly developing fields with important implications for critical supply chains; ILs are perfect for such applications and will be especially encouraged if they continue to be sold as a green solvent. Functionalized ILs, solid extraction, SILPs, and agricultural waste-based IL show great promise for sustainable high-value metal recovery. With proper optimization and funding supports, ILs will undoubtedly contribute to more sustainable and environmentally friendly technologies and processes.

Author Contributions: Conceptualization, I.C.N. and D.P.; methodology, I.C.N. and D.P.; validation, G.I., I.C.N. and D.P.; writing-original draft preparation, G.I.; writing-review and editing, G.I., I.C.N. and D.P.; visualization, G.I. and D.P.; supervision, I.C.N. and D.P.; project administration, I.C.N. and D.P. All authors have read and agreed to the published version of the manuscript. 
Funding: 1. U.S. Department of Energy, Office of Energy Efficiency and Renewable Energy, Advanced Manufacturing Office, Critical Materials Institute. 2. U.S. Department of Energy, Office of Science, Office of Workforce Development for Teachers and Scientists (WDTS) under the Science Undergraduate Laboratory Internships (SULI) program.

Institutional Review Board Statement: Not applicable.

Informed Consent Statement: Not applicable.

Acknowledgments: This work was supported by the Critical Materials Institute, an Energy Innovation Hub funded by the U.S. Department of Energy, Office of Energy Efficiency and Renewable Energy, Advanced Manufacturing Office. Ames Laboratory is operated for the U.S. DOE by Iowa State University of Science and Technology under Contract No. DE-AC02-07CH11358. This research was supported in part by the U.S. Department of Energy, Office of Science, Office of Workforce Development for Teachers and Scientists (WDTS) under the Science Undergraduate Laboratory Internships (SULI) program

Conflicts of Interest: The authors declare no conflict of interest.

\section{References}

1. King, A.H. Our elemental footprint. Nat. Mater. 2019, 18, 408-409. [CrossRef]

2. US DOE. Critical Materials Rare Earths Supply Chain: A Situational White Paper. Available online: https://www.energy.gov/ eere/amo/downloads / critical-materials-supply-chain-white-paper-april-2020 (accessed on 29 November 2021).

3. Herrington, R. Mining our green future. Nat. Rev. Mater. 2021, 6, 456-458. [CrossRef]

4. Kalantzakos, S. The Race for Critical Minerals in an Era of Geopolitical Realignments. Int. Spect. 2020, 55, 1-16. [CrossRef]

5. Rogers, R.D.; Seddon, K.R. Ionic Liquids—Solvents of the Future? Science 2003, 302, 792-793. Available online: https://www. science.org/doi/full/10.1126/science.1090313 (accessed on 29 November 2021). [CrossRef] [PubMed]

6. Welton, T. Ionic liquids: A brief history. Biophys. Rev. 2018, 10, 691-706. [CrossRef] [PubMed]

7. Forsyth, S.A.; Pringle, J.M.; MacFarlane, D.R. Ionic liquids-An overview. Aust. J. Chem. 2004, 57, 113-119. [CrossRef]

8. Cho, C.-W.; Pham, T.P.T.; Zhao, Y.; Stolte, S.; Yun, Y.-S. Review of the Toxic Effects of Ionic Liquids. Sci. Total Environ. 2021, 786, 147309. [CrossRef] [PubMed]

9. Pleshkova, N.V.; Seddon, K.R. Applications of ionic liquids in the chemical industry. Chem. Soc. Rev. 2008, 37, 123-150. [CrossRef]

10. Prodius, D.; Mudring, A.-V. Rare earth metal-containing ionic liquids. Coord. Chem. Rev. 2018, 363, 1-16. [CrossRef]

11. Kulkarni, P.S.; Branco, L.C.; Crespo, J.G.; Nunes, M.C.; Raymundo, A.; Afonso, C.A.M. Comparison of Physicochemical Properties of New Ionic Liquids Based on Imidazolium, Quaternary Ammonium, and Guanidinium Cations. Chem. Eur. J. 2007, 13, 8478-8488. [CrossRef]

12. Binnemans, K.; Jones, P.T. Solvometallurgy: An Emerging Branch of Extractive Metallurgy. J. Sustain. Metall. 2017, 3, 570-600. [CrossRef]

13. Paiva, A.P.; Nogueira, C.A. Ionic Liquids in the Extraction and Recycling of Critical Metals from Urban Mines. Waste Biomass Valorization 2021, 12, 1725-1747. [CrossRef]

14. Mai, N.L.; Ahn, K.; Koo, Y.-M. Methods for recovery of ionic liquids-A review. Process Biochem. 2014, 49, 872-881. [CrossRef]

15. Zhou, J.; Sui, H.; Jia, Z.; Yang, Z.; He, L.; Li, X. Recovery and purification of ionic liquids from solutions: A review. RSC Adv. 2018, 8, 32832-32864. [CrossRef]

16. Hajipour, A.R.; Rafiee, F. Recent Progress in Ionic Liquids and Their Applications in Organic Synthesis. Org. Prep. Proced. Int. 2015, 47, 249-308. [CrossRef]

17. Nockemann, P.; van Deun, R.; Thijs, B.; Huys, D.; Vanecht, E.; van Hecke, K.; van Meervelt, L.; Binnemans, K. Uranyl Complexes of Carboxyl-Functionalized Ionic Liquids. Inorg. Chem. 2010, 49, 3351-3360. [CrossRef]

18. Fan, F.L.; Qin, Z.; Cao, S.W.; Tan, C.M.; Huang, Q.G.; Chen, D.S.; Wang, J.R.; Yin, X.J.; Xu, C.; Feng, X.G. Highly Efficient and Selective Dissolution Separation of Fission Products by an Ionic Liquid [Hbet][Tf $\left.{ }_{2} \mathrm{~N}\right]$ : A New Approach to Spent Nuclear Fuel Recycling. Inorg. Chem. 2019, 58, 603-609. [CrossRef]

19. Rout, A.; Kotlarska, J.; Dehaen, W.; Binnemans, K. Liquid-Liquid Extraction of Neodymium (III) by Dialkylphosphate Ionic Liquids from Acidic Medium: The Importance of the Ionic Liquid Cation. Phys. Chem. Chem. Phys. 2013, 15, 16533-16541. [CrossRef]

20. Wang, K.; Adidharma, H.; Radosz, M.; Wan, P.; Xu, X.; Russell, C.K.; Tian, H.; Fan, M.; Yu, J. Recovery of Rare Earth Elements with Ionic Liquids. Green Chem. 2017, 4469-4493. [CrossRef]

21. Mohapatra, P.K. Actinide Ion Extraction Using Room Temperature Ionic Liquids: Opportunities and Challenges for Nuclear Fuel Cycle Applications. Dalton Trans. 2017, 46, 1730-1747. [CrossRef]

22. Sun, P.; Huang, K.; Liu, H. The Nature of Salt Effect in Enhancing the Extraction of Rare Earths by Non-Functional Ionic Liquids: Synergism of Salt Anion Complexation and Hofmeister Bias. J. Colloid Interface Sci. 2019, 539, 214-222. [CrossRef]

23. Lommelen, R.; Onghena, B.; Binnemans, K. Cation Effect of Chloride Salting Agents on Transition Metal Ion Hydration and Solvent Extraction by the Basic Extractant Methyltrioctylammonium Chloride. Inorg. Chem. 2020, 59, 13442-13452. [CrossRef] 
24. Fu, J.; Chen, Q.; Sun, T.; Shen, X. Extraction of Th (IV) from Aqueous Solution by Room-Temperature Ionic Liquids and Coupled with Supercritical Carbon Dioxide Stripping. Sep. Purif. Technol. 2013, 119, 66-71. [CrossRef]

25. Sepúlveda, R.; Romero, J.; Sánchez, J. Copper Removal from Aqueous Solutions by Means of Ionic Liquids Containing a $\beta$ Diketone and the Recovery of Metal Complexes by Supercritical Fluid Extraction. J. Chem. Technol. Biotechnol. 2014, 89, 899-908. [CrossRef]

26. Zhou, Y.; Boudesocque, S.; Mohamadou, A.; Dupont, L. Extraction of metal ions with task specific ionic liquids: Influence of a coordinating anion. Sep. Sci. Technol. 2015, 50, 38-44. [CrossRef]

27. Platzer, S.; Kar, M.; Leyma, R.; Chib, S.; Roller, A.; Jirsa, F.; Krachler, R.; MacFarlane, D.R.; Kandioller, W.; Keppler, B.K. Taskspecific thioglycolate ionic liquids for heavy metal extraction: Synthesis, extraction efficacies and recycling properties. J. Hazard. Mater. 2017, 324, 241-249. [CrossRef] [PubMed]

28. Dhiman, S.; Gupta, B. Recovery of pure germanium oxide from Zener diodes using a recyclable ionic liquid Cyphos IL 104. J. Environ. Manag. 2020, 276, 111218. [CrossRef] [PubMed]

29. Hagelüken, C.; Corti, C.W. Recycling of Gold from Electronics: Cost-Effective Use through 'Design for Recycling'. Gold Bull. 2010, 43, 209-220. [CrossRef]

30. van den Bossche, A.; de Witte, E.; Dehaen, W.; Binnemans, K. Trihalide Ionic Liquids as Non-Volatile Oxidizing Solvents for Metals. Green Chem. 2018, 20, 3327-3338. [CrossRef]

31. Alguacil, F.J. Non-Dispersive Extraction of Gold (III) with Ionic Liquid Cyphos IL101. Sep. Purif. Technol. 2017, 179, 72-76. [CrossRef]

32. Nguyen, V.T.; Lee, J.C.; Jeong, J.; Kim, B.S.; Cote, G.; Chagnes, A. Extraction of Gold (III) from Acidic Chloride Media Using Phosphonium-Based Ionic Liquid as an Anion Exchanger. Ind. Eng. Chem. Res. 2015, 54, 1350-1358. [CrossRef]

33. Wang, N.; Wang, Q.; Geng, Y.; Sun, X.; Wu, D.; Yang, Y. Recovery of Au (III) from Acidic Chloride Media by Homogenous Liquid-Liquid Extraction with UCST-Type Ionic Liquids. ACS Sustain. Chem. Eng. 2019, 7, 19975-19983. [CrossRef]

34. Wang, M.; Wang, Q.; Geng, Y.; Wang, N.; Yang, Y. Gold (III) Separation from Acidic Medium by Amine-Based Ionic Liquid. J. Mol. Liq. 2020, 304, 112735. [CrossRef]

35. Boudesocque, S.; Mohamadou, A.; Conreux, A.; Marin, B.; Dupont, L. The Recovery and Selective Extraction of Gold and Platinum by Novel Ionic Liquids. Sep. Purif. Technol. 2019, 210, 824-834. [CrossRef]

36. Guo, W.; Yang, F.; Zhao, Z.; Liao, Q.; Cai, C.; Zhang, Y.; Bai, R. Cellulose-Based Ionic Liquids as an Adsorbent for High Selective Recovery of Gold. Miner. Eng. 2018, 125, 271-278. [CrossRef]

37. Copper-The World's Most Reusable Resource. Available online: https://www.copper.org/environment/lifecycle/g_recycl.html (accessed on 29 November 2021).

38. Chen, M.; Huang, J.; Ogunseitan, O.A.; Zhu, N.; Wang, Y.M. Comparative Study on Copper Leaching from Waste Printed Circuit Boards by Typical Ionic Liquid Acids. Waste Manag. 2015, 41, 142-147. [CrossRef]

39. He, J.; Yang, J.; Tariq, S.M.; Duan, C.; Zhao, Y. Comparative Investigation on Copper Leaching Efficiency from Waste Mobile Phones Using Various Types of Ionic Liquids. J. Clean. Prod. 2020, 256, 120368. [CrossRef]

40. Janssen, C.H.C.; Macías-Ruvalcaba, N.A.; Aguilar-Martínez, M.; Kobrak, M.N. Copper Extraction Using Protic Ionic Liquids: Evidence of the Hofmeister Effect. Sep. Purif. Technol. 2016, 168, 275-283. [CrossRef]

41. Diabate, P.D.; Boudesocque, S.; Mohamadou, A.; Dupont, L. Separation of Cobalt, Nickel and Copper with Task-Specific Amido Functionalized Glycine-Betaine-Based Ionic Liquids. Sep. Purif. Technol. 2020, 244, 116782. [CrossRef]

42. Damilano, G.; Laitinen, A.; Willberg-Keyriläinen, P.; Lavonen, T.; Häkkinen, R.; Dehaen, W.; Binnemans, K.; Kuutti, L. Effects of Thiol Substitution in Deep-Eutectic Solvents (DESs) as Solvents for Metal Oxides. RSC Adv. 2020, 10, 23484-23490. [CrossRef]

43. PGMs Retain their Sheen. Available online: https:/ / www.recyclingtoday.com/article/platinum-group-metals-commodity-focus/ (accessed on 29 November 2021).

44. Regel-Rosocka, M.; Rzelewska, M.; Baczynska, M.; Janus, M.; Wisniewski, M. Removal of Palladium (II) from Aqueous Chloride Solutions with Cyphos Phosphonium Ionic Liquids as Metal Ion Carriers for Liquid-Liquid Extraction and Transport across Polymer Inclusion Membranes. Physicochem. Probl. Miner. Proc. 2015, 51, 621-631. [CrossRef]

45. Katsuta, S.; Tamura, J. Extraction of Palladium (II) and Platinum (IV) from Hydrochloric Acid Solutions with Trioctylammonium Nitrate Ionic Liquid without Dilution. J. Solut. Chem. 2018, 47, 1293-1308. [CrossRef]

46. Mokhodoeva, O.; Shkinev, V.; Maksimova, V.; Dzhenloda, R.; Spivakov, B. Recovery of Platinum Group Metals Using Magnetic Nanoparticles Modified with Ionic Liquids. Sep. Purif. Technol. 2020, 248, 117049. [CrossRef]

47. Funaki, K.; Ma, S.; Kawamura, S.; Miyazaki, A.; Sugie, A.; Mori, A.; Muramatsu, A.; Kanie, K. Metal-Selective DeprotectionMediated Palladium (II) Extraction by Ionic Liquids with Tetrahydropyran-2H-Yl-Protected Thiol Moieties. Chem. Lett. 2017, 46, 434-437. [CrossRef]

48. Olivetti, E.A.; Ceder, G.; Gaustad, G.G.; Fu, X. Lithium-Ion Battery Supply Chain Considerations: Analysis of Potential Bottlenecks in Critical Metals. Joule 2017, 1, 229-243. [CrossRef]

49. Abergel, T.; Bunsen, T.; Gorner, M.; Leduc, P. Global EV Outlook 2020: Entering the Decade of Electric Drive? OECD Publishing: Paris, France, 2020. [CrossRef]

50. Li, Z.; Mercken, J.; Li, X.; Riaño, S.; Binnemans, K. Efficient and Sustainable Removal of Magnesium from Brines for Lithium/Magnesium Separation Using Binary Extractants. ACS Sustain. Chem. Eng. 2019, 7, 19225-19234. [CrossRef] 
51. He, Q.; Williams, N.J.; Oh, J.H.; Lynch, V.M.; Kim, S.K.; Moyer, B.A.; Sessler, J.L. Selective Solid-Liquid and Liquid-Liquid Extraction of Lithium Chloride Using Strapped Calix[4]Pyrroles. Angew. Chem. 2018, 130, 12100-12104. [CrossRef]

52. Nelson, J.J.M.; Schelter, E.J. Sustainable Inorganic Chemistry: Metal Separations for Recycling. Inorg. Chem. 2019, 58, 979-990. [CrossRef]

53. Zante, G.; Boltoeva, M.; Masmoudi, A.; Barillon, R.; Trébouet, D. Lithium Extraction from Complex Aqueous Solutions Using Supported Ionic Liquid Membranes. J. Membr. Sci. 2019, 580, 62-76. [CrossRef]

54. Liu, G.; Zhao, Z.; He, L. Highly Selective Lithium Recovery from High Mg/Li Ratio Brines. Desalination 2020, $474,114185$. [CrossRef]

55. Roldán-Ruiz, M.J.; Ferrer, M.L.; Gutiérrez, M.C.; del Monte, F. Highly Efficient P-Toluenesulfonic Acid-Based Deep-Eutectic Solvents for Cathode Recycling of Li-Ion Batteries. ACS Sustain. Chem. Eng. 2020, 8, 5437-5445. [CrossRef]

56. Chen, Y.; Lu, Y.; Liu, Z.; Zhou, L.; Li, Z.; Jiang, J.; Wei, L.; Ren, P.; Mu, T. Efficient Dissolution of Lithium-Ion Batteries Cathode LiCoO 2 by Polyethylene Glycol-Based Deep Eutectic Solvents at Mild Temperature. ACS Sustain. Chem. Eng. 2020, 8, 11713-11720. [CrossRef]

57. Recycling Cathode of Lithium-Ion Battery by Using Deep Eutectic Solvents to Extract Cobalt. Available online: https://www. diva-portal.org/smash/get/diva2:1448722/FULLTEXT01.pdf (accessed on 29 November 2021).

58. Tran, M.K.; Rodrigues, M.-T.F.; Kato, K.; Babu, G.; Ajayan, P.M. Deep Eutectic Solvents for Cathode Recycling of Li-Ion Batteries. Nat. Energy 2019, 4, 339-345. [CrossRef]

59. Peeters, N.; Binnemans, K.; Riaño, S. Solvometallurgical Recovery of Cobalt from Lithium-Ion Battery Cathode Materials Using Deep-Eutectic Solvents. Green Chem. 2020, 22, 4210-4221. [CrossRef]

60. A New Process for Cobalt-Nickel Separation. Available online: https://www.teck.com/media/CESL-Publication-Nickel-NewProcess-Cobalt-Nickel-Separation-2010.pdf (accessed on 29 November 2021).

61. Wellens, S.; Thijs, B.; Möller, C.; Binnemans, K. Separation of Cobalt and Nickel by Solvent Extraction with Two Mutually Immiscible Ionic Liquids. Phys. Chem. Chem. Phys. 2013, 15, 9663-9669. [CrossRef] [PubMed]

62. Sun, X.; Ji, Y.; Hu, F.; He, B.; Chen, J.; Li, D. The Inner Synergistic Effect of Bifunctional Ionic Liquid Extractant for Solvent Extraction. Talanta 2010, 81, 1877-1883. [CrossRef]

63. Wellens, S.; Thijs, B.; Binnemans, K. An Environmentally Friendlier Approach to Hydrometallurgy: Highly Selective Separation of Cobalt from Nickel by Solvent Extraction with Undiluted Phosphonium Ionic Liquids. Green Chem. 2012, 14, 1657-1665. [CrossRef]

64. Onghena, B.; Opsomer, T.; Binnemans, K. Separation of Cobalt and Nickel Using a Thermomorphic Ionic-Liquid-Based Aqueous Biphasic System. Chem. Commun. 2015, 51, 15932-15935. [CrossRef]

65. Othman, E.A.; van der Ham, A.G.J.; Miedema, H.; Kersten, S.R.A. Recovery of Metals from Spent Lithium-Ion Batteries Using Ionic Liquid [P $\left.\mathrm{P}_{8888}\right][$ Oleate]. Sep. Purif. Technol. 2020, 252, 117435. [CrossRef]

66. Zante, G.; Braun, A.; Masmoudi, A.; Barillon, R.; Trébouet, D.; Boltoeva, M. Solvent Extraction Fractionation of Manganese, Cobalt, Nickel and Lithium Using Ionic Liquids and Deep Eutectic Solvents. Miner. Eng. 2020, 156, 106512. [CrossRef]

67. Shanks, W.C.P., III; Kimball, B.E.; Tolcin, A.C.; Guberman, D.E. Germanium and Indium. In Critical Mineral Resources of the United States_Economic and Environmental Geology and Prospects for Future Supply; Schulz, K.J., DeYoung, J.H., Jr., Seal, R.R., II, Bradley, D.C., Eds.; U.S. Geological Survey Professional Paper; U.S. Geological Survey: Reston, VA, USA, 2017 ; pp. 1-27. [CrossRef]

68. Deferm, C.; Onghena, B.; Nguyen, V.T.; Banerjee, D.; Fransaer, J.; Binnemans, K. Non-Aqueous Solvent Extraction of Indium from an Ethylene Glycol Feed Solution by the Ionic Liquid Cyphos IL 101: Speciation Study and Continuous Counter-Current Process in Mixer-Settlers. RSC Adv. 2020, 10, 24595-24612. [CrossRef]

69. van Roosendael, S.; Regadío, M.; Roosen, J.; Binnemans, K. Selective Recovery of Indium from Iron-Rich Solutions Using an Aliquat 336 Iodide Supported Ionic Liquid Phase (SILP). Sep. Purif. Technol. 2019, 212, 843-853. [CrossRef]

70. Alguacil, F.J.; Escudero, E. Solvent Extraction of Indium (III) from HCl Solutions by the Ionic Liquid (A324H+) (Cl-) Dissolved in Solvesso 100. Hydrometallurgy 2019, 189, 105104. [CrossRef]

71. Luo, D.; Zhu, N.; Li, Y.; Cui, J.; Wu, P.; Wang, J. Simultaneous Leaching and Extraction of Indium from Waste LCDs with Acidic Ionic Liquids. Hydrometallurgy 2019, 189, 105146. [CrossRef]

72. Matsumiya, M.; Sumi, M.; Uchino, Y.; Yanagi, I. Recovery of Indium Based on the Combined Methods of Ionic Liquid Extraction and Electrodeposition. Sep. Purif. Technol. 2018, 201, 25-29. [CrossRef]

73. Monnens, W.; Deferm, C.; Sniekers, J.; Fransaer, J.; Binnemans, K. Electrodeposition of Indium from Non-Aqueous Electrolytes. Chem. Commun. 2019, 55, 4789-4792. [CrossRef]

74. van Roosendael, S.; Roosen, J.; Banerjee, D.; Binnemans, K. Selective Recovery of Germanium from Iron-Rich Solutions Using a Supported Ionic Liquid Phase (SILP). Sep. Purif. Technol. 2019, 221, 83-92. [CrossRef]

75. Nguyen, T.H.; Lee, M.S. A Review on Germanium Resources and Its Extraction by Hydrometallurgical Method. Miner. Process. Extr. Metall. Rev. 2020, 42, 406-426. [CrossRef]

76. Kamran Haghighi, H.; Irannajad, M.; Fortuny, A.; Sastre, A.M. Recovery of Germanium from Leach Solutions of Fly Ash Using Solvent Extraction with Various Extractants. Hydrometallurgy 2018, 175, 164-169. [CrossRef]

77. Kamran Haghighi, H.; Irannajad, M.; Fortuny, A.; Sastre, A.M. Selective Separation of Germanium (IV) from Simulated Industrial Leachates Containing Heavy Metals by Non-Dispersive Ionic Extraction. Miner. Eng. 2019, 137, 344-353. [CrossRef] 
78. Ruiz, A.G.; Sola, P.C.; Moreno Palmerola, N.M. Germanium: Current and Novel Recovery Processes. In Advanced Material and Device Applications with Germanium; Lee, S., Ed.; InTechOpen: London, UK, 2018; Available online: https://doi.org/10.5772/ intechopen.77997 (accessed on 29 November 2021).

79. Endres, F.; Zein El Abedin, S. Nanoscale Electrodeposition of Germanium on Au (111) from an Ionic Liquid: An in Situ STM Study of Phase Formation. Part II. Ge from $\mathrm{GeCl}_{4}$. Phys. Chem. Chem. Phys. 2002, 4, 1649-1657. [CrossRef]

80. Yu, Z.; Meng, X.; Yin, M.; Sun, M.; Yuan, M.; Li, H. Pulsed Laser-Assisted Ionic Liquid Electrodeposition of Gallium Nanoparticles and Germanium Nanostructures for Energy Storage. Chem. Phys. Lett. 2018, 698, 181-186. [CrossRef]

81. van den Bossche, A.; Vereycken, W.; vander Hoogerstraete, T.; Dehaen, W.; Binnemans, K. Recovery of Gallium, Indium, and Arsenic from Semiconductors Using Tribromide Ionic Liquids. ACS Sustain. Chem. Eng. 2019, 7, 14451-14459. [CrossRef]

82. Raiguel, S.; Dehaen, W.; Binnemans, K. Extraction of Gallium from Simulated Bayer Process Liquor by Kelex 100 Dissolved in Ionic Liquids. Dalton Trans. 2020, 49, 3532-3544. [CrossRef] [PubMed]

83. Kinsman, L.M.M.; Morrison, C.A.; Ngwenya, B.T.; Love, J.B. Reducing the Competition: A Dual-Purpose Ionic Liquid for the Extraction of Gallium from Iron Chloride Solutions. Molecules 2020, 25, 4047. [CrossRef] [PubMed]

84. Nassar, N.T.; Fortier, S.M. Methodology and Technical Input for the 2021 Review and Revision of the U.S. Critical Minerals List. In U.S. Geological Survey Open-File Report 2021-1045; U.S. Geological Survey: Reston, VA, USA, 2021; 31p. Available online: https:/ / pubs.er.usgs.gov/publication/ofr20211045 (accessed on 29 November 2021).

85. Li, Z.; Diaz, L.A.; Yang, Z.; Jin, H.; Lister, T.E.; Vahidi, E.; Zhao, F. Comparative Life Cycle Analysis for Value Recovery of Precious Metals and Rare Earth Elements from Electronic Waste. Resour. Conserv. Recycl. 2019, 149, 20-30. [CrossRef]

86. Zuo, Y.; Liu, Y.; Chen, J.; de Li, Q. The Separation of Cerium (IV) from Nitric Acid Solutions Containing Thorium (IV) and Lanthanides (III) Using Pure [ $\left.\mathrm{C}_{8} \mathrm{mim}\right] \mathrm{PF}_{6}$ as Extracting Phase. Ind. Eng. Chem. Res. 2008, 47, 2349-2355. [CrossRef]

87. Nakashima, K.; Kubota, F.; Maruyama, T.; Goto, M. Feasibility of Ionic Liquids as Alternative Separation Media for Industrial Solvent Extraction Processes. Ind. Eng. Chem. Res. 2005, 44, 4368-4372. [CrossRef]

88. Rout, A.; Binnemans, K. Influence of the Ionic Liquid Cation on the Solvent Extraction of Trivalent Rare-Earth Ions by Mixtures of Cyanex 923 and Ionic Liquids. Dalton Trans. 2014, 44, 1379-1387. [CrossRef]

89. Sun, X.; Bell, J.R.; Luo, H.; Dai, S. Extraction Separation of Rare-Earth Ions via Competitive Ligand Complexations between Aqueous and Ionic-Liquid Phases. Dalton Trans. 2011, 40, 8019-8023. [CrossRef]

90. Jensen, M.P.; Neuefeind, J.; Beitz, J.V.; Skanthakumar, S.; Soderholm, L. Mechanisms of Metal Ion Transfer into Room-Temperature Ionic Liquids: The Role of Anion Exchange. J. Am. Chem. Soc. 2003, 125, 15466-15473. [CrossRef] [PubMed]

91. Kubota, F.; Koyanagi, Y.; Nakashima, K.; Shimojo, K.; Kamiya, N.; Goto, M. Extraction of Lanthanide Ions with an Organophosphorous Extractant into Ionic Liquids. Solvent Extr. Res. Dev. 2008, 15, 81-87.

92. Kubota, F.; Shimobori, Y.; Baba, Y.; Koyanagi, Y.; Shimojo, K.; Kamiya, N.; Goto, M. Application of Ionic Liquids to Extraction Separation of Rare Earth Metals with an Effective Diglycol Amic Acid Extractant. J. Chem. Eng. Jpn. 2011, 44, 307-312. [CrossRef]

93. Dupont, D.; Binnemans, K. Recycling of Rare Earths from NdFeB Magnets Using a Combined Leaching/Extraction System Based on the Acidity and Thermomorphism of the Ionic Liquid [Hbet][Tf ${ }_{2}$ N]. Green Chem. 2015, 17, 2150-2163. [CrossRef]

94. Wang, W.; Yang, H.; Cui, H.; Zhang, D.; Liu, Y.; Chen, J. Application of Bifunctional Ionic Liquid Extractants [A336][CA-12] and [A336][CA-100] to the Lanthanum Extraction and Separation from Rare Earths in the Chloride Medium. Ind. Eng. Chem. Res. 2011, 50, 7534-7541. [CrossRef]

95. Rout, A.; Binnemans, K. Solvent Extraction of Neodymium (III) by Functionalized Ionic Liquid Trioctylmethylammonium Dioctyl Diglycolamate in Fluorine-Free Ionic Liquid Diluent. Ind. Eng. Chem. Res. 2014, 53, 6500-6508. [CrossRef]

96. Khodakarami, M.; Alagha, L. Separation and Recovery of Rare Earth Elements Using Novel Ammonium-Based Task-Specific Ionic Liquids with Bidentate and Tridentate O-Donor Functional Groups. Sep. Purif. Technol. 2020, 232, 115952. [CrossRef]

97. Sun, X.; Waters, K.E. Development of Industrial Extractants into Functional Ionic Liquids for Environmentally Friendly Rare Earth Separation. ACS Sustain. Chem. Eng. 2014, 2, 1910-1917. [CrossRef]

98. Sun, X.; Luo, H.; Dai, S. Mechanistic Investigation of Solvent Extraction Based on Anion-Functionalized Ionic Liquids for Selective Separation of Rare-Earth Ions. Dalton Trans. 2013, 42, 8270-8275. [CrossRef]

99. Guo, X.; Yao, W.; Chen, Y.; Fan, J.; Zhao, Y.; Wang, J. PEG-Functionalized Ionic Liquids: A Class of Liquid Materials for Highly Efficient Extraction of Rare Earth Metals from Aqueous Solutions. J. Mol. Liq. 2017, 236, 308-313. [CrossRef]

100. Önal, M.A.R.; Dewilde, S.; Degri, M.; Pickering, L.; Saje, B.; Riaño, S.; Walton, A.; Binnemans, K. Recycling of Bonded NdFeB Permanent Magnets Using Ionic Liquids. Green Chem. 2020, 22, 2821-2830. [CrossRef]

101. Orefice, M.; van den Bulck, A.; Blanpain, B.; Binnemans, K. Selective Roasting of Nd-Fe-B Permanent Magnets as a Pretreatment Step for Intensified Leaching with an Ionic Liquid. J. Sustain. Met. 2020, 6, 91-102. [CrossRef]

102. Prodius, D.; Gandha, K.; Mudring, A.V.; Nlebedim, I.C. Sustainable Urban Mining of Critical Elements from Magnet and Electronic Wastes. ACS Sustain. Chem. Eng. 2020, 8, 1455-1463. [CrossRef]

103. Riaño, S.; Sobekova Foltova, S.; Binnemans, K. Separation of Neodymium and Dysprosium by Solvent Extraction Using Ionic Liquids Combined with Neutral Extractants: Batch and Mixer-Settler Experiments. RSC Adv. 2019, 10, 307-316. [CrossRef]

104. Prodius, D.; Klocke, M.; Smetana, V.; Alammar, T.; Perez Garcia, M.; Windus, T.L.; Nlebedim, I.C.; Mudring, A.-V. Rationally Designed Rare Earth Separation by Selective Oxalate Solubilization. Chem. Commun. 2020, 56, 11386-11389. [CrossRef]

105. Sobekova Foltova, S.; vander Hoogerstraete, T.; Banerjee, D.; Binnemans, K. Samarium/Cobalt Separation by Solvent Extraction with Undiluted Quaternary Ammonium Ionic Liquids. Sep. Purif. Technol. 2019, 210, 209-218. [CrossRef] 
106. Orefice, M.; Audoor, H.; Li, Z.; Binnemans, K. Solvometallurgical Route for the Recovery of Sm, Co, Cu and Fe from SmCo Permanent Magnets. Sep. Purif. Technol. 2019, 219, 281-289. [CrossRef]

107. Dupont, D.; Binnemans, K. Rare-Earth Recycling Using a Functionalized Ionic Liquid for the Selective Dissolution and Revalorization of $\mathrm{Y}_{2} \mathrm{O}_{3}$ :Eu ${ }^{3+}$ from Lamp Phosphor Waste. Green Chem. 2015, 17, 856-868. [CrossRef]

108. Pateli, I.M.; Abbott, A.P.; Binnemans, K.; Rodriguez Rodriguez, N. Recovery of Yttrium and Europium from Spent Fluorescent Lamps Using Pure Levulinic Acid and the Deep Eutectic Solvent Levulinic Acid-Choline Chloride. RSC Adv. 2020, 10, 28879-28890. [CrossRef]

109. Sanchez-Cupido, L.; Pringle, J.M.; Siriwardana, A.L.; Unzurrunzaga, A.; Hilder, M.; Forsyth, M.; Pozo-Gonzalo, C. WaterFacilitated Electrodeposition of Neodymium in a Phosphonium-Based Ionic Liquid. J. Phys. Chem. Lett. 2019, 10, $289-294$. [CrossRef]

110. Entezari-Zarandi, A.; Larachi, F. Selective Dissolution of Rare-Earth Element Carbonates in Deep Eutectic Solvents. J. Rare Earths 2019, 37, 528-533. [CrossRef]

111. Liu, C.; Yan, Q.; Zhang, X.; Lei, L.; Xiao, C. Efficient Recovery of End-of-Life NdFeB Permanent Magnets by Selective Leaching with Deep Eutectic Solvents. Environ. Sci. Technol. 2020, 54, 10370-10379. [CrossRef] [PubMed]

112. Riaño, S.; Petranikova, M.; Onghena, B.; vander Hoogerstraete, T.; Banerjee, D.; Foreman, M.R.S.; Ekberg, C.; Binnemans, K. Separation of Rare Earths and Other Valuable Metals from Deep-Eutectic Solvents: A New Alternative for the Recycling of Used NdFeB Magnets. RSC Adv. 2017, 7, 32100-32113. [CrossRef]

113. Avdibegović, D.; Regadío, M.; Binnemans, K. Efficient Separation of Rare Earths Recovered by a Supported Ionic Liquid from Bauxite Residue Leachate. RSC Adv. 2018, 8, 11886-11893. [CrossRef]

114. Avdibegović, D.; Binnemans, K. Separation of Scandium from Hydrochloric Acid-Ethanol Leachate of Bauxite Residue by a Supported Ionic Liquid Phase. Ind. Eng. Chem. Res. 2020, 59, 15332-15342. [CrossRef]

115. Avdibegović, D.; Yagmurlu, B.; Dittrich, C.; Regadío, M.; Friedrich, B.; Binnemans, K. Combined Multi-Step Precipitation and Supported Ionic Liquid Phase Chromatography for the Recovery of Rare Earths from Leach Solutions of Bauxite Residues. Hydrometallurgy 2018, 180, 229-235. [CrossRef]

116. Li, Z.; Onghena, B.; Li, X.; Zhang, Z.; Binnemans, K. Enhancing Metal Separations Using Hydrophilic Ionic Liquids and Analogues as Complexing Agents in the More Polar Phase of Liquid-Liquid Extraction Systems. Ind. Eng. Chem. Res. 2019, 58, 15628-15636. [CrossRef]

117. Panigrahi, M.; Grabda, M.; Kozak, D.; Dorai, A.; Shibata, E.; Kawamura, J.; Nakamura, T. Liquid-Liquid Extraction of Neodymium Ions from Aqueous Solutions of $\mathrm{NdCl}_{3}$ by Phosphonium-Based Ionic Liquids. Sep. Purif. Technol. 2016, 171, 263-269. [CrossRef]

118. Li, F.; Zeng, J.; Sun, X. Functionalized Ionic Liquids Based on Vegetable Oils for Rare Earth Elements Recovery. RSC Adv. 2020, 10, 26671-26674. [CrossRef]

119. Iqbal, M.; Waheed, K.; Rahat, S.B.; Mehmood, T.; Lee, M.S. An overview of molecular extractants in room temperature ionic liquids and task specifc ionic liquids for the partitioning of actinides/lanthanides. J. Radioanal. Nucl. Chem. 2020, 325, 1-31. [CrossRef]

120. Taebi, B.; Kloosterman, J.L. To Recycle or Not to Recycle? An Intergenerational Approach to Nuclear Fuel Cycles. Sci. Eng. Ethics 2008, 14, 177-200. [CrossRef]

121. Leoncini, A.; Huskens, J.; Verboom, W. Ligands for F-Element Extraction Used in the Nuclear Fuel Cycle. Chem. Soc. Rev. 2017, 46, 7229-7273. [CrossRef]

122. Zarrougui, R.; Mdimagh, R.; Raouafi, N. Highly Efficient Extraction and Selective Separation of Uranium (VI) from Transition Metals Using New Class of Undiluted Ionic Liquids Based on H-Phosphonate Anions. J. Hazard. Mater. 2018, 342, 464-476. [CrossRef]

123. Irish, E.R.; Reas, W.H. The PUREX Process-A Solvent Extraction Reprocessing Method for Irradiated Uranium; HW-49483-A; General Electric Company Hanford Atomic Products Operation: Washington, DC, USA, 1957; Available online: https://doi.org/10.2172/ 4341712 (accessed on 29 November 2021).

124. Sun, X.; Luo, H.; Dai, S. Ionic Liquids-Based Extraction: A Promising Strategy for the Advanced Nuclear Fuel Cycle. Chem. Rev. 2012, 112, 2100-2128. [CrossRef] [PubMed]

125. Rao, C.J.; Venkatesan, K.A.; Nagarajan, K.; Srinivasan, T.G. Dissolution of Uranium Oxides and Electrochemical Behavior of U(VI) in Task Specific Ionic Liquid. Radiochim. Acta 2008, 96, 403-409. [CrossRef]

126. Moyer, B.A.; Lumetta, G.J.; Mincher, B.J. Minor Actinide Separation in the Reprocessing of Spent Nuclear Fuels: Recent Advances in the United States. In Reprocessing and Recycling of Spent Nuclear Fuel; Taylor, R., Ed.; Woodhead Publishing: Oxford, UK, 2015; pp. 289-312. Available online: https:/ / doi.org/10.1016/B978-1-78242-212-9.00011-3 (accessed on 29 November 2021).

127. Sun, X.; Do-Thanh, C.L.; Luo, H.; Dai, S. The Optimization of an Ionic Liquid-Based TALSPEAK-like Process for Rare Earth Ions Separation. Chem. Eng. J. 2014, 239, 392-398. [CrossRef]

128. Taylor, R.J.; Gregson, C.R.; Carrott, M.J.; Mason, C.; Sarsfield, M.J. Progress towards the Full Recovery of Neptunium in an Advanced PUREX Process. Solvent Extr. Ion Exch. 2013, 31, 442-462. [CrossRef]

129. Zsabka, P.; van Hecke, K.; Wilden, A.; Modolo, G.; Verwerft, M.; Binnemans, K.; Cardinaels, T. Selective Extraction of Americium from Curium and the Lanthanides by the Lipophilic Ligand $\mathrm{CyMe}_{4}$ BTPhen Dissolved in Aliquat-336 Nitrate Ionic Liquid. Solvent Extr. Ion Exch. 2020, 38, 194-211. [CrossRef] 
130. Zsabka, P.; Opsomer, T.; van Hecke, K.; Dehaen, W.; Wilden, A.; Modolo, G.; Verwerft, M.; Binnemans, K.; Cardinaels, T. Solvent Extraction Studies for the Separation of Trivalent Actinides from Lanthanides with a Triazole-Functionalized 1,10-Phenanthroline Extractant. Solvent Extr. Ion Exch. 2020, 38, 719-734. [CrossRef]

131. An Americium-Fueled Gas Core Nuclear Rocket. Available online: https://doi.org/10.1063/1.43073 (accessed on 29 November 2021).

132. Hansen, B.B.; Spittle, S.; Chen, B.; Poe, D.; Zhang, Y.; Klein, J.M.; Horton, A.; Adhikari, L.; Zelovich, T.; Doherty, B.W.; et al. Deep Eutectic Solvents: A Review of Fundamentals and Applications. Chem. Rev. 2021, 121, 1232-1285. Available online: https:/ / pubs.acs.org/doi/10.1021/acs.chemrev.0c00385 (accessed on 29 November 2021). [CrossRef] [PubMed]

133. Ni, S.; Su, J.; Zhang, H.; Zeng, Z.; Zhi, H.; Sun, X. A cleaner strategy for comprehensive recovery of waste SmCo magnets based on deep eutectic solvents. Chem. Eng. J. 2021, 412, 128602. [CrossRef]

134. Zürner, P.; Frisch, G. Leaching and Selective Extraction of Indium and Tin from Zinc Flue Dust Using an Oxalic Acid-Based Deep Eutectic Solvent. ACS Sustain. Chem. Eng. 2019, 7, 5300-5308. Available online: https://pubs.acs.org/doi/10.1021/ acssuschemeng.8b06331 (accessed on 29 November 2021). [CrossRef]

135. Yu, G.; Zhao, D.; Wen, L.; Yang, S.; Chen, X. Viscosity of Ionic Liquids: Database, Observation, and Quantitative Structure-Property Relationship Analysis. AIChE J. 2012, 58, 2885-2899. [CrossRef]

136. Zhao, Y.; Zhao, J.; Huang, Y.; Zhou, Q.; Zhang, X.; Zhang, S. Toxicity of Ionic Liquids: Database and Prediction via Quantitative Structure-Activity Relationship Method. J. Hazard. Mater. 2014, 278, 320-329. [CrossRef] [PubMed]

137. Hora, P.I.; Pati, S.G.; McNamara, P.J.; Arnold, W.A. Increased Use of Quaternary Ammonium Compounds during the SARS-CoV-2 Pandemic and Beyond: Consideration of Environmental Implications. Environ. Sci. Technol. Lett. 2020, 7, 622-631. [CrossRef]

138. Ionic Liquids: Environmentally Sustainable Solvent, Energy Storage and Separation Processes. Available online: https://www. bccresearch.com/market-research/chemicals/ionic-liquids-market-research-report.html (accessed on 29 November 2021). 